\title{
REGEN-COV protects against viral escape in preclinical and human studies
}

Richard Copin ${ }^{1, \dagger}$, Alina Baum ${ }^{1, \dagger}$, Elzbieta Wloga ${ }^{1}$, Kristen E. Pascal ${ }^{1}$, Stephanie

Giordano ${ }^{1}$, Benjamin O. Fulton ${ }^{1}$, Anbo Zhou ${ }^{1}$, Nicole Negron ${ }^{1}$, Kathryn Lanza ${ }^{1}$, Newton

Chan ${ }^{1}$, Angel Coppola ${ }^{1}$, Joyce Chiu ${ }^{1}$, Min Ni ${ }^{1}$, Yi Wei ${ }^{1}$, Gurinder S. Atwal ${ }^{1}$, Annabel

Romero Hernandez ${ }^{1}$, Kei Saotome ${ }^{1}$, Yi Zhou ${ }^{1}$, Matthew C. Franklin ${ }^{1}$, Andrea T.

Hooper $^{1}$, Shane McCarthy ${ }^{1}$, Sara Hamon ${ }^{1}$, Jennifer D. Hamilton ${ }^{1}$, Hilary M. Staples ${ }^{2}$, Kendra Alfson ${ }^{2}$, Ricardo Carrion, $\mathrm{Jr}^{2}$, Shazia Ali ${ }^{1}$, Thomas Norton ${ }^{1}$, Selin SomersanKarakaya $^{1}$, Sumathi Sivapalasingam ${ }^{1}$, Gary A. Herman ${ }^{1}$, David M. Weinreich ${ }^{1}$, Leah Lipsich $^{1}$, Neil Stahl ${ }^{1}$, Andrew J. Murphy ${ }^{1}$, George D. Yancopoulos ${ }^{1}$, Christos A. Kyratsous ${ }^{1, *}$

*Correspondence to: christos.kyratsous@regeneron.com.

† These authors contributed equally to this work

\section{Affiliations:}

${ }^{1}$ Regeneron Pharmaceuticals, Inc., Tarrytown, NY 10591

2 Southwest National Primate Research Center, Texas Biomedical Research Institute, San Antonio, TX 78245. 


\section{Summary}

Monoclonal antibodies against SARS-CoV-2 are a clinically validated therapeutic option against COVID-19. As rapidly emerging virus mutants are becoming the next major concern in the fight against the global pandemic, it is imperative that these therapeutic treatments provide coverage against circulating variants and do not contribute to development of treatment emergent resistance. To this end, we investigated the sequence diversity of the spike protein and monitored emergence of minor virus variants in SARS-COV-2 isolates found in COVID-19 patients or identified from preclinical in vitro and in vivo studies. This study demonstrates that a combination of non-competing antibodies, REGEN-COV, not only provides full coverage against current variants of concern/interest but also protects against emergence of new such variants and their potential seeding into the population in a clinical setting. 


\section{Introduction}

The coronavirus disease 2019 (COVID-19) global pandemic has motivated a widespread effort to understand adaptation of its etiologic agent, the severe acute respiratory syndrome coronavirus 2 (SARS-CoV-2). Similar to all viruses, SARS-CoV-2 is constantly evolving, mutants are selected due to a fitness advantage, which can be associated with an ability to spread more efficiently in the human population or to overcome natural or vaccine-mediated immune responses. Ongoing viral evolution is a major concern for direct antivirals, especially for therapeutics targeting the main proteins recognized by humoral immunity, such as the viral glycoproteins. Such mutations can provide a fitness advantage in the context of drug treatment; therefore they can be rapidly selected during therapy, and may lead to treatment failure and/or spread of treatment resistant-associated variants. To date, multiple studies have investigated the development of viral resistance against neutralizing monoclonal antibodies (mAbs) targeting the SARS-CoV-2 spike protein (Baum et al., 2020a; Liu et al., 2021b; Weisblum et al., 2020) spreads in humans and the mechanisms driving resistance during treatment is necessary to ensure optimal efficacy of antivirals.

REGEN-COV (previously known as REGN-COV2) is a cocktail of two fully-human noncompeting, neutralizing antibodies - casirivimab (REGN10933) and imdevimab (REGN10987) - that target the receptor binding domain (RBD) on the SARS-CoV-2 spike protein and thereby prevent viral entry into the host cell (Hansen et al., 2020). The strategic decision to include a pair of highly potent non-competing antibodies that can simultaneously bind to distinct, non-overlapping epitopes of the RBD was made to safeguard against the rapid emergence of drug resistant variants and provide coverage against circulating viral variants (Baum et al., 2020a). In vitro studies showed that combining two non-competing antibodies protected against rapid escape seen with its individual single-antibody components (Baum et al., 2020a). Additionally, the benefit of this combination approach has been supported by subsequent studies showing that REGEN-COV retains neutralization potency against emerging SARS-CoV-2 variants potentially associated with increased infectivity (e.g. D614G and UK B.1.1.7 variants), 
as well as those associated with reduced vaccine-induced neutralization titers or vaccine efficacy (e.g. South Africa B.1.351), even when one of its components has partially reduced activity (Garcia-Beltran et al., 2021; Liu et al., 2021a; Madhi et al., 2021; Wang et al., 2021; Yurkovetskiy et al., 2020):-1.]. Concerns regarding single antibody approaches in the clinic are emerging, based on increasing prevalence of naturally circulating variants resistant to these single agents(Wang et al., 2021):-is], and reports within clinical studies that single antibody treatment is associated with the emergence of resistant (FDA, 2021)

Although in vitro escape studies using recombinant viruses strongly support the rationale of using non-competing antibody combinations to avoid drug resistance, questions remain regarding the relevance of these findings to authentic SARS-CoV-2 virus, to in vivo infection models, and most importantly, to the clinical setting. In this work we first show that in vitro escape variants are rapidly selected against all individual clinical-stage antibodies targeting the RBD of the spike protein, independent of the targeted epitope or its degree of conservation, that such risk can be mitigated by utilizing combinations of two non-competing antibodies, and even further reduced by combining three non-competing antibodies. We extend these findings by showing that escape variants can also be efficiently selected in vivo upon treatment with individual antibodies, independent of dosage or treatment setting (prophylaxis or therapy), while the REGEN-COV combination fully protects against development of such resistance. Importantly, we confirm these findings in humans; we investigated the genetic diversity of the entire spike protein across 4,882 samples from 1,000 outpatients or hospitalized patients with confirmed COVID-19 from ongoing Phase 1-3 trials (Weinreich et al., 2021, 2020) (clinicaltrials.gov NCT04666441, NCT04426695, NCT04452318). Analysis of baseline and post-treatment sequence diversity in placebo and REGEN-COV treated patients demonstrated that the non-competing antibody combination protects against selection of drug resistant variants. 


\section{Results}

We previously generated a large library of fully human monoclonal antibodies targeting the spike protein of SARS-CoV-2 and selected REGN10933 + REGN10987 as a pair of potently neutralizing molecules that can simultaneously bind to their target (Hansen et al., 2020). We hypothesized that this non-competing antibody combination would retain its potency as the virus evolves in the human population and safeguard against selection of escape mutants following treatment (Baum et al., 2020a; Tegally et al., 2020)

With the recent rise in rapidly emerging variants, we are able to test this hypothesis by evaluating the potency of the individual antibodies as well as the REGEN-COV combination against variants of concern/interest as defined by the Centers for Disease Control and Precention (CDC), including B.1.1.7(UK), B.1.427/B.1429 (California), B.1.351 (South Africa), P.1(Brazil), B.1.526 (New York), B.1.617.1/B.1.717.2/B.1.617.3 (India) lineages (CDC, 2021; Davies et al., 2021; Nonaka et al., 2021; Tegally et al., 2020; West et al., 2021; Zhang et al., 2021) Importantly, even in instances where one of the antibodies is impacted, the combination retains full neutralization potency, a key property through which this combination of antibodies was originally selected, thus maintaining coverage against all assessed variants (Fig. 1A\&B).

We have previously shown that combination therapy with two anti-spike antibodies targeting non-overlapping epitopes of the SARS-CoV-2 spike protein minimizes the likelihood of rapid viral escape observed in vitro with monotherapy (Baum et al., 2020), as has also been demonstrated by others (Dong et al., 2021; Weisblum et al., 2020). Expanding on our previous work using VSV-SARS-CoV-2-spike recombinant virus to monitor resistance to $\mathrm{mAb}$ treatment, we now performed such escape studies with several RBD targeting mAbs approved under Emergency Use Authorization (EUA) or in late-stage clinical trials, and tested monotherapy as well as dual and triple combinations. We found that while only one to two passages led to complete virus resistance against all mAbs used as monotherapy, seven consecutive passages were needed to reach complete resistance to the REGEN-COV combination, requiring 
selection of multiple simultaneous mutations impacting each antibody (Fig.2A\&B). Escape variants identified with COV2-2130, COV2-2196, and COV555 antibodies were consistent with those previously described for these molecules (Table S1) (Dong et al., 2021; FDA, 2021) Similar to the REGEN-COV combination, the COV2-2130 and COV2-2196 cocktail was also resistant to rapid escape and full escape was associated with acquiring multiple mutations within the same virus (Fig.2A)(Dong et al., 2021) contrast, the LY-CoV555/CB6 combination behaved similarly to monotherapy, where rapid escape driven by a single amino acid substitution was observed. Such rapid escape from combinations of competing antibodies has been demonstrated in our previous studies and is expected based on the overlapping nature of the LY-CoV555 and CB6 epitopes(Baum et al., 2020a; Jones et al., 2021; Shi et al., 2020; Starr et al., 2021):슬.

Importantly, rapid escape observed in the monotherapy setting was independent of the targeted epitope or its sequence conservation as escape variants were rapidly selected against an antibody targeting a broad coronavirus epitope, VIR-7831 (Pinto et al., 2020) (Fig. 2A, Table S1). All VIR-7831 escape residues mapped to the published epitope of the antibody and the resultant escape virus maintained its ability to replicate, indicating that these mutations were not deleterious to the virus (data not shown). Furthermore, the identified escape variants can be found in publicly available genome sequences (GISAID), indicating that they are tolerated by the authentic SARS-CoV-2 virus and thus are likely to be selected under pressure. These experiments highlight the inherent risk of monotherapy against SARS-CoV-2 with any anti-spike mAb, regardless of the targeted epitope or its conservation.

We have previously described a triple antibody combination against Zaire ebolavirus (Pascal et al., 2018) and we similarly decided to assess potential advantages of combining three non-competing neutralizing mAbs targeting the RBD of SARS-CoV2:REGN10933+REGN10987+REGN10985. As part of an effort to structurally characterize our SARS-CoV-2 neutralizing antibodies, we determined a cryo-EM structure of REGN10985 (plus another antibody, REGN10989) bound to RBD (Supp. 
Fig. 4). REGN10985 binds to a broad patch on the side of the RBD, directly below the region contacted by ACE2. Although there is very little overlap between the ACE2 and REGN10985 contact surfaces on the RBD, the REGN10985 Fab is angled so that it overlaps with the space that ACE2 would occupy, making this antibody a direct blocker of ACE2 binding like REGN10933 and REGN10987. By combining this cryoEM structure with our previously-determined structure of REGN10933+REGN10987+RBD (Hansen et al., 2020) we produced a model of the three-antibody complex showing that all three mAbs are able to bind simultaneously to the RBD of the spike protein in a nonoverlapping fashion (Figure 2C). We additionally demonstrated that the three-antibody combination has similar neutralization potency as REGEN-COV (Figure 2B). We found that addition of the third non-competing RBD mAb further increased protection against viral escape, with no loss of antiviral potency observed through eleven consecutive passages (Figure 2A, Table S1). These results demonstrate that a three mAb neutralizing non-competing combination targeting the spike RBD provides a potential further advantage as a SARS-CoV-2 therapeutic.

To understand how these in vitro escape findings demonstrating that mAb combination treatments safeguard against development of drug resistance translate to a more physiological setting, we evaluated virus evolution in vivo following mAb administration as both monotherapy (REGN10987 or REGN10933) and as the REGEN-COV combination in the SARS-CoV-2 hamster challenge model. Animals were challenged with SARS-CoV-2 (USA-WA1/2020) and treated with either high or low dose (50mg/kg or $5 \mathrm{mg} / \mathrm{kg}$ ) of either REGN10987 or REGN10933 as monotherapy or with the REGENCOV combination $(50 \mathrm{mg} / \mathrm{kg}$ or $5 \mathrm{mg} / \mathrm{kg}$ ) in both prophylactic and treatment settings (Figure 3A). These doses were previously shown to provide partial or complete efficacy in this animal model with REGEN-COV (Baum et al., 2020b). Lungs from infected animals were collected on day 7 post-challenge, presumably after the virus has had an opportunity to go through multiple rounds of replication, to isolate viral RNA. RNAseq analysis was used to detect variants in the spike protein present even at low frequencies in the virus population (>5\%). To identify putative treatment resistant variants, we focused our analysis on the spike RBD, where the REGEN-COV antibodies 
are known to bind, and where all previously identified resistant variants to either antibody are located. Analysis of the RBD sequence in saline treated animals did not reveal any variants, indicating that in the absence of treatment the virus is not under strong selection pressure in this model (Fig. 3B\&C). However, several variants in the RBD were identified in animals treated with either of the single antibodies as monotherapy (Fig. 3B\&C). Remarkably, our analysis demonstrated selection of resistance variants in almost half (18/40) of monotherapy treated animals versus none $(0 / 20)$ of the animals treated with the REGEN-COV combination. Out of the 7 RBD variants identified in monotherapy treated animals, 6 have been previously described as resistance variants or mapped to the same amino acid position as other resistance variants to either REGN10933 or REGN10987 (Table S3). Four of these variants were previously identified in our in vitro escape studies, validating the relevance of using VSV-SARS-CoV-2-spike recombinant virus to identify SARS-CoV-2 escape mutations (Baum et al., 2020a). Interestingly, variant selection occurred with monotherapy treatment in both the prophylactic and therapeutic settings, and in both low and high dose groups. Although rare unique variants outside of the RBD were also identified in a single animal treated with the REGEN-COV combination (Fig. 3B\&C), the low frequency of these variants and their location well outside the epitopes of the antibodies make it extremely unlikely that they were associated with the REGEN-COV treatment.

To assess the emergence of drug resistance in REGEN-COV treated COVID-19 patients, we characterized the genetic diversity of 1,336 and 3,546 SARS-CoV-2 RNA samples isolated from 272 hospitalized and 728 non-hospitalized individuals, respectively, at baseline and several time points post mAb cocktail administration (Table S2). In both hospitalized and non-hospitalized study groups, patients were randomly assigned (1:1:1) to receive placebo, $2.4 \mathrm{~g}$ of REGEN-COV, or $8.0 \mathrm{~g}$ of REGEN-COV, and patient samples were collected at multiple time points from baseline (day 1) to study end point (day 29). RNA-seq analysis was performed to characterize the genetic diversity of the spike sequence from all swabs positive for SARS-CoV-2 RNA by qRTPCR. Minor variants present at a frequency of at least $15 \%$ in the virus population were identified. In total, 244 and 514 amino acid changes were identified across all samples 
from hospitalized and non-hospitalized patients, respectively. For both studies, variant counts and frequencies in all three treatment groups were similar, indicating that REGEN-COV did not increase spike protein diversity relative to placebo (Table S2).

To determine whether REGEN-COV treatment contributed to selection of resistant variants in the spike protein, we longitudinally compared the frequency of minor variants in each patient from all available RT-PCR positive samples. Among all patient samples from the hospitalized group, we identified a total of 89, 87 and 108 amino acid changes in the placebo, low-dose and high dose treated groups, respectively. These mutations were evenly spread across the entire spike protein sequence (Fig. 4A\&B). The low number of variants in the RBD found among samples from patients treated with REGEN-COV further demonstrated lack of treatment emergent selection relative to placebo (15 RBD variants in placebo versus 12 low-dose/12 high-dose in REGEN-COV treated group). Only 17\% (42/244) of all amino acid changes were observed at more than one time point in at least one patient (Fig. 4B) indicating that the vast majority of variants were lost over time likely as a result of lack of fitness or population bottlenecks. Three of these variants were found in the RBD in the REGEN-COV treated groups only (S477N, N501T and K537R). The S477N variant was present in 7 REGEN-COV treated patients at multiple time points, including baseline (Fig. S1). S477N is a common SARSCoV-2 variant present at a frequency of $>5 \%$ viruses circulating worldwide (source: GISAID). K537R was identified in 1 treated patient and is a rare mutation, which has been found in only <10 virus isolates worldwide to date (Fig. 5, source: GISAID). N501T was observed in 3 treated patients in this study (Fig. 5). Of note, in all patients, the three variants were identified at baseline or earliest time points ( $<5$ days after REGEN-COV treatment) and no significant increase in their frequencies between early and late time points were observed indicating absence of treatment related selection.

We identified a total of 216, 248 and 212 amino acid changes among the 1,215 placebo, 1,203 low-dose and 1,128 high-dose REGEN-COV treated patient samples respectively from the non-hospitalized group, spread across the entire spike protein sequence (Fig. 6). The RBD contained respectively, 23, 27 and 31 amino acid changes among which 
S477N and only 2 other variants (S494P and G446V) were identified at more than one time point in at least one REGEN-COV treated patient (Fig. 6B). The S477N variant was present in 3 REGEN-COV and 5 placebo treated patients at multiple time points, including baseline (Figure S2). S494P is a rare circulating mutation ( 0.15\% GIDAID) only found at multiple time points (including baseline) in 2 REGEN-COV treated patients. G446V is a rare variant ( $\sim 0.02 \%$ GISAID) identified in 4 REGEN-COV treated and 2 placebo patients (Fig. 7). One of these patients (Fig. 7 - Patient B4), represented the only example with a consistent late increase in the relative frequency of the variant, however, it should be pointed out that there is no evidence that the absolute frequency of the variant increased over time as viral levels dropped dramatically over time. For all G446V patients, including Patient B4, we observed that the frequency of variants was decreased to undetectable at the latest time points, indicating that drug mediated selection is unlikely.

To determine the functional impact of RBD variants identified at multiple time points in REGEN-COV treated patients, individual antibodies and the combination were assessed for neutralization potency against the G446V, S494P, S477N, and K537R variants (Fig. S3). Decrease in neutralization potency was observed with REGN10987 (135-fold) against the G446V variant, and minimally with REGN10933 (4.5-fold) against the S494P variant, whereas no impact was observed on either mAb with the S477N or K537R variants. The N501T variant was not assessed but an alternative substitution N501Y did not show any impact on either antibody or the REGEN-COV combination. Importantly, in all instances the REGEN-COV combination retained full neutralization potency, thereby providing its full antiviral activity in treated individuals and limiting any potential selection of resistant variants. 


\section{Discussion}

The increasing use of monoclonal antibodies as a clinically validated therapeutic option against SARS-CoV-2 raises questions about which of these therapies may be impacted by circulating and rapidly emerging variants and which may induce treatment emergent resistance. The recent recognition that some immunodominant residues in the spike protein, such as E484K, often impact both $m A b$ therapies and vaccine-induced immune responses makes it imperative to ensure that $\mathrm{mAb}$ treatments not only provide protection against common circulating variants, but to also ensure that treatmentinduced escape variants are not seeded into the population, where they may contribute to undermining efficacy of other therapeutics or vaccines (Greaney et al., 2021; Wang et al., 2021). Real-world manifestations of such concerns are demonstrated by the recent withdrawal of emergency use authorization of bamlanivimab monotherapy due to high prevalence of the B.1.526 and B.1.427/B.1429 variants, as well as the recent US government recommendation against the use of the bamlanivimab/estevimab combination in Illinois and Massachusetts due to high prevalence of the P.1 variant, which impacts both antibodies in the combination(HHS, 2021b, 2021a).

To date, we and others have identified antibody resistant variants through in vitro escape studies and have demonstrated that combinations of two non-competing antibodies provide protection against rapid viral escape (Baum et al., 2020a; Weisblum et al., 2020). We hypothesized that a cocktail of three non-competing antibodies could further delay emergence of resistance. Although, neutralizing antibodies against the $\mathrm{N}$ terminal domain (NTD) of spike have been described (Liu et al., 2020), this region is frequently deleted in emerging variants (Wang et al., 2021), therefore such molecules are not ideal as therapeutics. We thus screened for and identified a third, noncompeting, RBD-binding $\mathrm{mAb}$ and now show that a triple antibody combination containing this $\mathrm{mAb}$ is even less susceptible to escape than the double combination.

However, the question regarding the relevance of these in vitro escape studies remains, and it is important to examine viral dynamics under therapeutic antibody pressure in more relevant settings, including in in vivo efficacy models and in treated patients. Our 
study, for the first time, provides evidence that in vitro escape studies with recombinant virus are highly predictive of in vivo selection. Indeed, we are able to show that in animals and in humans, the relative risk of selecting for spike variants that are resistant to treatment is predicted by in vitro findings. Treatment with the single antibody components of the REGEN-COV combination results in rapid selection of escape variants, whereas the combination protects against viral escape in vitro, in vivo, and in COVID-19 patients. Furthermore, by comparing escape mutations identified through in vitro assays utilizing recombinant VSV-based virus to those identified in SARS-CoV-2 infected hamsters, we show that many identical mutations are identified in both settings, further validating the in vitro findings.

Understanding pathogen population diversity and selection within the infected host has important implications for understanding virus evolution and resistance processes, and for proper identification of appropriate drug treatments. To date, the vast majority of SARS-CoV-2 sequencing data has come from global surveillance efforts and reporting of consensus sequences that include fixed mutations in isolates obtained from independent individuals. This is the first large-scale report describing, within individual patients, the longitudinal evolution of the SARS-CoV-2 virus population. Moreover, this study is the first to evaluate the effects of antiviral antibody treatment on virus evolution in humans. As predicted by our in vitro and in vivo preclinical studies, treatment with the REGEN-COV cocktail in the clinic did not seemingly select for resistant variants nor appreciably alter virus evolution. Our approach allowed us to observe minor variants and our data indicate the vast majority of infected individuals are already harboring spike protein variants at baseline, prior to use of any antiviral agent and before natural immunity is established, as half of the study participants had not yet mounted an antiviral immune response at baseline (Weinreich et al., 2020). Indeed, from our clinical sequencing data we can observe multiple variants in amino acid residues identified in our in vitro escape studies expected to impact clinical antibody candidates, including VIR-7831 (P337, T345) and COV-2196 (G476) as well as our own individual antibodies. This clearly demonstrates that the SARS-CoV-2 circulating population is highly heterogeneous in infected patients and the large reservoir of existing (or future) minor 
variants could be readily selected under the right selective pressure conditions. Indeed, treatment emergent resistant variants have been reported in clinical studies in which patients were treated with anti-SARS-CoV-2 antibody monotherapy (FDA, 2021).

Although the REGEN-COV combination maintains its neutralization potency against all variants of interest/concern to date, one of its components (REGN10933) demonstrates partially decreased potency against some variants. This highlights the potential risk that even non-competing combination therapies may not retain their full advantages in some geographical regions with high prevalence of select variants of concern. Thus, active surveillance of circulating viruses and development of next-generation antibody combinations where multiple components maintain coverage against emerging variants should be an important focus for the future of antiviral mAb therapeutics. This type of approach will require agility and may need to be analogous to the framework applied to seasonal updates of influenza vaccine components, where new anti-spike mAbs are substituted or added as necessary to maintain optimal efficacy against a rapidly mutating pathogen.

To ensure optimal and sustained efficacy, an antiviral therapeutic intervention should be prospectively designed to not only have coverage against major circulating variants, but also to prevent the selection of minor escape variants. And although the risk of viral resistance cannot be completely eliminated, it can be greatly reduced through selection of optimal combination therapies. This study demonstrates that carefully designed antibody combinations can achieve both of these critical objectives.

\section{Limitations of the Study}

The current study focused on assessing likelihood of identifying REGEN-COV mediated selection of resistant viral variants in treated COVID-19 patients and overall predictability of preclinical in vitro and in vivo escape studies to human patients. Our data clearly demonstrated that treatment with any RBD-directed mAb monotherapy results in rapid selection of drug resistant viral variants. However, although we did not identify any clear selection of resistant variants in the clinical population after treatment 
with REGEN-COV, it was impossible for us to directly compare monotherapy and combination therapy in the clinical setting due to the combination nature of our therapeutic. Thorough sequencing of viral samples post-treatment with clinical monotherapy products may help to provide clinical data on likelihood of resistance in that setting. Furthermore, although we assessed over 3000 samples from 1000 patients in our study to identify potential REGEN-COV associated selection of variants it is possible that this sample size may not be large enough to identify very rare events. 


\section{Acknowledgements}

The authors would like to thank Kristen Tramaglini, Yasmin Khan, Lisa Boersma and Sarah Whittleton for their continuous support.

\section{Author Contributions}

A.B. and C.A.K. conceptualized the studies. E. W., K.E.P., S.G., and B.O.F. conducted escape studies and neutralization assays. A.Z., N.N., K.L., N.C., A.C., J.C., M.N., Y.W., and G.S.A. performed RNA sequencing and data analysis. H.M.S., K.A., and R.C. carried out the hamster experiments. A.R.H., K.S., Y.Z., and M.C.F. performed structural analysis. A.T.H., J.D.H., S.A., T.N., S.S-K., S.S., G.A.H., D.M.W planned and carried out clinical studies. A.T.H., J.D.H. oversaw clinical sample and data acquisition. S.M., and S.H. oversaw clinical data acquisition and data analysis. L.L. oversaw program direction. R.C., A.B., N.S., A.J.M, G.D.Y, C.A.K analyzed data. R.C., A.B., G.D.Y., C.A.K. wrote the manuscript.

\section{Funding}

A portion of this project has been funded in whole or in part with Federal funds from the Department of Health and Human Services; Office of the Assistant Secretary for Preparedness and Response; Biomedical Advanced Research and Development Authority, under OT number: HHSO100201700020C.

\section{Declaration of Interests}

Regeneron authors own options and/or stock of the company. This work has been described in one or more pending provisional patent applications. G.S.A., G.H., D.M.W., L.L, N.S, A.J.M., G.D.Y. and C.A.K. are officers of Regeneron. 
Figure Legends

Figure 1: Neutralization of variants of concern and variants of interest by the REGEN-COV combination and individual antibodies. A) Neutralization curves and B) Neutralization fold-decrease relative to parental D614G variant. Full UK B.1.1.7 (H69del, V70del, Y145del, N501Y, A570D, D614G, P681H, T716I, S982A, D1118H), South African B.1.351 (D80Y, D215Y, L241del, L242del, A243del, L242del, K417N, E484K, N501Y, D614G, A701V) and P.1 (L18F, T20N, P26S, D138Y, R190S, K417T, E484K, N501Y, D614G, H655Y, T1027I, V1176F) variants were assessed. Key RBD residues from B.1.429 California (L452R) and B.1.617.1 India (L452R/E484Q) and B.1.617.2 India (L452R/T478K) variants were assessed. The E484K variant has been identified in many global lineages, including the B.1.526 New York, P.2 Brazil and B.1.618 India lineages.

Figure 2: In vitro escape with individual antibodies and antibody combinations. VSV-spike recombinant virus was passaged under pressure of individual antibodies or antibody combinations. A) passage number during which the virus completely escaped neutralizing activity of the antibodies as evidenced by the cytopathic effect (CPE), is shown as "complete escape" for wells where antibody concentration was $10 \mathrm{ug} / \mathrm{ml}$ or above or "partial escape" for wells where antibody concentration was $1-10 \mathrm{ug} / \mathrm{ml}$. B) Neutralization potency of the two mAb REGN10987+REGN10933 combination and the three mAb REGN10987+REGN10933+REGN10987+REGN10985 combination along with individual mAbs $C$ ) Two views of the RBD-REGN10933-REGN10987-REGN10985 model. RBD is colored white; REGN10933 is shown blue, REGN10987 is shown in red and REGN10985 is shown in green. Surface representation of the RBD in white with contact patches for each antibody, colors as in panel A.

Figure 3: Frequency of SARS-CoV-2 spike variants identified in viruses from lungs of hamsters treated with either REGN10987 or REGN10933 as monotherapy or with the REGEN-COV combination in both prophylactic and treatment settings.

A) Study design. B ,C) Graphs show the distribution and frequencies of amino acid 
variants across the spike protein sequence identified in samples from the B) prophylactic or $\mathbf{C}$ ) treated groups. Mutated sites are indicated with grey lines and dots show the frequency of variants in each animal. The color of each dot indicated the dose used. Spike protein domain are color coded as indicated and all amino acid changes in RBD are labeled.

\section{Figure 4: Variant analysis of virus sequences in SARS-CoV-2 positive samples} from hospitalized patients. Graphs show the distribution of amino acid variants across the spike protein sequence identified in samples from the placebo, REGEN-COVIowdose and REGEN-COVhigh-dose treated patients. Mutated sites are indicated with arrows and arrow length designate the number of patients with 1 or more variantcontaining samples. Spike protein domains are color coded as indicated and all amino acid changes in RBD are labeled. A) Arrows highlight variants identified in 1 or more samples from at least one patient. B) Arrows highlight variants identified in 2 or more samples from at least one patient. All samples were characterized by the defining Glycine substitution at position 614.

Figure 5: Viral load and longitudinal frequencies of variants in REGN-COV2treated, SARS-CoV-2 positive samples from hospitalized patients. Viral load was determined by quantitative RT-PCR. A) N501T and B) K537R variant frequencies are indicated by the black line as percent of reads with nSNPs relative to total number of covering reads. Histograms show total (blue) and mutated (magenta) read coverage at variant position.

\section{Figure 6: Variant analysis of virus sequences in SARS-CoV-2 positive samples} from non-hospitalized patients. Graphs show the distribution of amino acid variants across the spike protein sequence identified in samples from the placebo, REGEN-COV low-dose and REGEN-COV high-dose treated patients. Mutated sites are indicated with arrows and arrow length designate the number of patients with 1 or more variantcontaining samples. Spike protein domains are color coded as indicated and all amino acid changes in RBD are labeled. A) Arrows highlight variants identified in 1 or more 
samples from at least one patient. B) Arrows highlight variants identified in 2 or more samples from at least one patient. All samples were characterized by the defining Glycine substitution at position 614.

Figure 7: Viral load and longitudinal frequencies of variants in SARS-CoV-2 positive samples from non-hospitalized patients. Viral load was determined by quantitative RT-PCR. A) S494P, B) G446V and variant frequencies are indicated by the black line as percent of reads with nSNPs relative to total number of covering reads. Histograms show total (blue) and mutated (magenta) read coverage at variant position. 


\section{Supplemental Figures}

Figure S1: Viral load and longitudinal frequencies of S477N in SARS-CoV-2 positive samples from hospitalized patients. Viral load was determined by quantitative RT-PCR. Variant frequencies are indicated by the black line as percent of reads with nSNPs relative to total number of covering reads. Histograms show total (blue) and mutated (magenta) read coverage at variant position.

Figure S2: Viral load and longitudinal frequencies of S477N in SARS-CoV-2 positive samples from non-hospitalized patients. Viral load was determined by quantitative RT-PCR. Variant frequencies are indicated by the black line as percent of reads with nSNPs relative to total number of covering reads. Histograms show total (blue) and mutated (magenta) read coverage at variant position.

Figure S3: Clinical variant neutralization by the REGEN-COV combination and individual antibodies. Variants identified in two or more samples from at least one patient in either the hospitalized or outpatient trial were assessed for impact on neutralization potency. A) Neutralization curves and B) Fold-change decrease versus parental D614G virus. *The N501Y variant was used to substitute for N501T.

Figure S4: Cryo-EM structure of RBD-REGN10989-REGN10985 in surface representation. RBD is in white, REGN10985 in green and REGN19089 in orange.

Table S1: Resistance mutations identified through in vitro escape studies. Mutations is spike protein identified through RNAseq analysis of supernatants from wells with complete escape selected under each antibody condition are listed in the table. The frequency of each mutation from total viral reads at that amino acid position is listed in prentices. Only those mutations that were present at frequencies above $15 \%$ are shown as more minor variants are unlikely to contribute to complete escape. 
Table S2: Summary of variant frequency for each clinical group from study 2066 and 2067. The table includes the patient, sample and amino acid change counts for each study. Frequency of the variants in all samples sequenced is indicated in parenthesis.

\section{Table S3: Relative neutralization potency of REGEN-COV combination and} individual antibodies against spike protein variants identified in hamster lungs. Decrease in neutralization potency relative to the parental virus is shown for each variant identified through RNAseq analysis of hamster lung RNA. * In cases where neutralization potency was not available (N/A) with the exact variant identified in infected hamsters, data is shown for an alternative variant at same position.

Table S4: Sample count and collection days for each clinical group from study 2066 and 2067 


\section{Methods}

\section{RESOURCE AVAILABILITY}

\section{Lead contact}

Further information and requests for resources and reagents should be directed to and will be fulfilled by the Lead Contact, Christos Kyratsous

(christos.kyratsous@regeneron.com).

\section{Materials availability}

Regeneron materials described in this manuscript may be made available to qualified, academic, noncommercial researchers through a materials transfer agreement upon request at https://regeneron.envisionpharma.com/vt regeneron/. For questions about how Regeneron shares materials, use the email address preclinical.collaborations@regeneron.com.

\section{Data and code availability}

All relevant data are available from the authors upon request. Protein Data Bank (PDB) identification number for the SARS-CoV-2 RBD complex with REGN10985 and REGN10989 Fabs is 7M42. The corresponding cryo-EM map is in the Electron Microscopy Data Bank (EMDB) with identification number EMD-23662.

\section{EXPERIMENTAL MODEL AND SUBJECT DETAILS}

\section{Human Subjects}

The outpatient study is an ongoing adaptive, multicenter, randomized, double-blind, placebo-controlled, seamless phase 1/2/3 clinical trial in COVID-19 outpatients (clinicaltrials.gov: NCT04425629). Non-hospitalized patients $>18$ years of age with a SARS-CoV2-positive test result $<72$ hours, and symptom onset $<10$ days before 
randomization, were randomized 1:1:1 to receive placebo, $2.4 \mathrm{~g}(1.2 \mathrm{~g}$ each of casirivimab and imdevimab) or $8.0 \mathrm{~g}$ ( $4.0 \mathrm{~g}$ each of casirivimab and imdevimab).

The hospitalized study is an ongoing adaptive, multicenter, randomized, double-blind, placebo-controlled, seamless phase 1/2/3 clinical trial in hospitalized patients with Covid-19 (clinicaltrials.gov: NCT04426695). Hospitalized patients $>18$ years of age with a SARS-CoV2-positive test result $<72$ hours, and symptom onset $<7$ days before randomization, were randomized $1: 1: 1$ to receive placebo, $2.4 \mathrm{~g}(1.2 \mathrm{~g}$ each of casirivimab and imdevimab) or $8.0 \mathrm{~g}$ ( $4.0 \mathrm{~g}$ each of casirivimab and imdevimab).

\section{Animals}

A total of 80 golden hamsters, male, approximately 9 weeks of age $(130-150 \mathrm{~g})$ were used in the study. Animals were housed one to five per cage; caging complies with the cage requirements (type, floor space, height, etc.) of the Animal Welfare Act and the Guide for the Care and Use of Laboratory Animals. Animals were acclimated to ABSL-3 laboratory conditions prior to exposure. In the ABSL-3, prior to virus exposure, animals were observed at least once daily, and after virus exposure animals will be observed at least twice daily for morbidity and mortality. On Day -2 relative to exposure, animals were sedated and received treatment via intraperitoneal injection.

\section{Cells}

African green monkey kidney cells (Vero, ATCC CCL-81), Vero clone E6 (Vero E6, ATCC CRL-1586), and human embryonic kidney cells (293T, ATCC CRL-3216), were maintained at $37^{\circ} \mathrm{C}$ and $5 \% \mathrm{CO}_{2}$ and cultured in high glucose Dulbecco's Modified Eagle's Medium without glutamine (DMEM; Life Technologies ) supplemented with 10\% fetal bovine serum (FBS; Life Technologies ) and 1\% Penicillin/Streptomycin/Lglutamine (Life Technologies).

\section{Viruses}

SARS-CoV-2 generated from isolate USA-WA1/2020 was used for animal exposures. A fourth cell-culture passage (P4) of SARS-CoV-2 was obtained from Biodefense and 
Emerging Infections Research Resources Repository (BEI Resources, catalog number NR-52281, GenBank accession number MN985325.1) and propagated at Texas Biomed. The stock virus was passaged for a fifth time in Vero E6 cells at a multiplicity of infection (MOI) of approximately 0.001 . This master stock was used to generate a sixth cell culture passage exposure stock by infecting VeroE6 cells at an $\mathrm{MOI}$ of 0.02 . The resulting stock had a titer of $1.2 \times 10^{6} \mathrm{PFU} / \mathrm{mL}$. The exposure stock has been confirmed to be SARSCoV-2 by deep sequencing and was identical to the published sequence (MN985325.1) at the consensus level.

\section{METHOD DETAILS}

\section{Generation of recombinant VSV}

Non-replicative pseudoparticles were generated using a VSV genome encoding the firefly luciferase and GFP genes instead of the native viral glycoprotein (VSV-G). Infectious particles complemented with VSV-G (VSV-AG-Fluc-2A-GFP/VSV-G) were recovered and produced using standard techniques with minor modifications (Baum et al., 2020a; Hansen et al., 2020; Lawson et al., 1995). HEK293T cells (ATCC CRL-3216) were plated on poly-lysine treated plates and incubated overnight in DMEM without glutamine (Life Technologies), 10\% fetal bovine serum (Life Technologies) and 1\% Penicillin/Streptomycin/L-glutamine (Life Technologies). The following day, the cells were transfected with the VSV genomic clone driven by a T7 promoter and helper plasmids expressing the VSV-N, VSV-P, VSV-G, VSV-L, and T7 RNA polymerase with Lipofectamine LTX reagent (Life Technologies). After 48 hours, the transfected cells were co-cultured with BHK-21 cells (ATCC CCL-10) transfected with VSV-G using the SE cell Line 4D-Nucleofector X Kit L (Lonza) in DMEM without glutamine (Life Technologies), $3 \%$ fetal bovine serum (Life Technologies) and $1 \%$ Penicillin/Streptomycin/L-glutamine (Life Technologies). Cells were monitored for GFP expression or cytopathic effect (CPE) indicative of virus replication. Virus was then plaque purified, expanded, and titered in BHK-21 cells transiently expressing VSV-G. Fully replicative VSV-SARS-CoV-2-S virus was generated by replacing the VSV 
glycoprotein with the native SARS-CoV-2 sequences encoding residues 1-1255 of the spike protein (MN908947.3). VSV-SARS-CoV-2-Spike virus was recovered as described above but the HEK293T cells were instead cocultured with BHK-21 cells transfected with both VSV-G and hACE2. VSV-SARS-CoV-2-S virus was plaque purified and titered in Vero cells (ATCC CCL-81) and expanded in Vero E6 cells (ATCC $\mathrm{CRL}-1586)$. After collection, stocks of both viruses were centrifuged at 3000xg for 5 minutes to clarify, sucrose cushioned to concentrate 10-fold, aliquoted, and frozen at $80 \mathrm{C}$.

\section{Pseudotyping of VSV}

Non-replicative pseudoparticles were generated as previously described (Baum et al 2020). Human codon-optimized SARS-CoV-2 spike (MN908947.3) was cloned into an expression plasmid. A total of $1.2 \times 107$ HEK293T cells (ATCC CRL-3216) were seeded overnight in 15-cm dishes in DMEM without glutamine (Life Technologies) containing 10\% heat-inactivated fetal bovine serum (Life Technologies), and PenicillinStreptomycin-L-Glutamine (Life Technologies). The following day, the cells were transfected with 15ug spike expression plasmid with Lipofectamine LTX (Life Technologies) following the manufacturer's protocol. At 24 hours post transfection, the cells were washed with phosphate buffered saline (PBS) and infected at a MOI of 1 with the VSV- $\triangle$ G-Fluc-2A-GFP/VSV-G virus diluted in 10mL Opti-MEM (Life Technologies). The cells were incubated 1 hour at $37 \mathrm{C}$ with $5 \%$ CO2. Cells were washed three times with PBS to remove residual input virus and overlaid with DMEM with glutamine (Life Technologies) with 0.7\% IgG-free BSA (Sigma), sodium pyruvate (Life Technologies), and Gentamicin (Life Technologies). After 24 hours at 37C with 5\% CO2, the supernatant containing pseudoparticles was collected, centrifuged at 3000xg for 5 minutes to clarify, aliquoted, and frozen at $-80 \mathrm{C}$. Variants were cloned into the spike expression plasmid using site-directed mutagenesis and pseudoparticles were produced as described above.

Neutralization assays with VSV based pseudoparticles. 
Vero cells (ATCC: CCL-81) were seeded in 96-well black, clear bottom tissue culture treated plated (Corning: 3904) at 20,000 cells/well in DMEM media without glutamine (Life Technologies) containing 10\% heat-inactivated fetal bovine serum (Life Technologies), and 1X Penicillin/Streptomycin/L-Glutamine (Life Technologies) 24 hours prior to assay. Cells were allowed to reach approximately $85 \%$ confluence before use in assay. Antibodies were diluted in Infection Media containing DMEM with glutamine (Life Technologies), 0.7\% Low IgG BSA (Sigma), 1X Sodium Pyruvate (Life Technologies), and $0.5 \%$ Gentamicin (Life Technologies) to $2 \mathrm{X}$ assay concentration and diluted 3-fold down in Infection media, for an 11-point dilution curve in the assay beginning at $3 \mathrm{ug} / \mathrm{mL}(20 \mathrm{nM})$. Antibody dilutions were mixed 1:1 with pseudoparticles for 30 minutes at room temperature prior to addition onto Vero cells. Cells were incubated at 37C, 5\% CO2 for 24 hours. Supernatant was removed from cells prior to lysis with 100 uL Glo Lysis Buffer (Promega). 100 uL resuspended Bright Glo substrate (Promega) was then added and luminescence was read on a Spectramax i3x (Molecular Devices). Exported values were analyzed using GraphPad Prism (v8.4.1)

\section{In vitro Escape Studies}

Escape studies were performed with recombinant VSV-SARS-CoV-2-Spike virus as previously described (Baum et al., 2020a). Escape variants were selected by incubating VSV-SARS-CoV-2-Spike under antibody pressure ranging from $0.016 \mathrm{ug} / \mathrm{mL}$ to $50 \mathrm{ug} / \mathrm{mL}$. After 30 minutes of incubation, the mixture was used to infect $2.5 \times 10^{\wedge} 5$ Vero (ATCC: CCL-81) or 3×10^5 Vero E6 (ATCC CRL-1586) cells at a multiplicity of infection (MOI) of 5 . Virus replication was monitored by screening for cytopathic effect over 96 hours. The supernatant and cellular RNA was collected from the wells with the highest antibody concentration with evident virus replication. The RNA was then subjected to RNAseq to identify spike protein variants. For subsequent rounds of selection,100uL of supernatant containing the virus was passaged under the same or greater antibody concentrations as in previous passages until complete CPE was observed after antibody treatment at concentration of $\geq 10 \mathrm{ug} / \mathrm{mL}$.

\section{Hamster Study}


A total of 80 golden hamsters, male, approximately 9 weeks of age (130-150g) were used in the study. Animals were weighed prior to the start of the study. The animals were monitored twice daily for signs of COVID-19 disease (ruffled fur, hunched posture, responsiveness, nasal discharge, labored breathing, a.o.) during the study period. Body weights were measured once daily during the study period. Antibodies were dosed through intraperitoneal (IP) injection $(0.200 \mathrm{ml}$ volume). Animals were challenged with 1x10^4 PFU of (USA-WA1/2020 (NR-52281; BEl Resources) by administration of $0.05 \mathrm{ml}$ total of viral inoculum, $0.025 \mathrm{ml}$ dropwise into each nostril (mock exposed animals received the same volume of sterile PBS). Prior to treatment and virus administration, animals were sedated using inhalational isoflurane. At study end (day 7 post-challenge), animals were euthanized via inhalational $\mathrm{CO}_{2}$ and tissues samples were aseptically collected for RNAseq. The day 7 time-point was selected for RNA collection and analysis as the virus has had ample ability to replicate in the animal allowing for detection of selected variants. Tissue samples were inactivated using Trizol Reagent (Invitrogen, Carlsbad, CA, USA). All animal studies were conducted in compliance with all relevant local, state, and federal regulations and were approved by the Texas Biomed Institutional Animal Care and Use Committee (IACUC; protocol number 1739MA).

\section{Clinical Trial Design}

Outpatient clinical trial

This is an ongoing adaptive, multicenter, randomized, double-blind, placebo-controlled, seamless phase 1/2/3 clinical trial in COVID-19 outpatients (clinicaltrials.gov: NCT04425629). Non-hospitalized patients > 18 years of age with a SARS-CoV2positive test result $<72$ hours, and symptom onset $<10$ days before randomization, were randomized 1:1:1 to receive placebo, $2.4 \mathrm{~g}(1.2 \mathrm{~g}$ each of casirivimab and imdevimab) or $8.0 \mathrm{~g}$ (4.0 g each of casirivimab and imdevimab). The primary virologic endpoint was the time weighted average daily change in viral load from baseline (Day 1) through Day 7. The key secondary clinical endpoint was the proportion of patients with 1 or more Covid-19 related medically-attended visit (MAV) through Day 29. For the 
present work, 3523 nasopharyngeal, 17 nasal and 6 saliva samples retrieved from a total of 728 patients were analyzed.

Hospitalized patient clinical trial

This is an ongoing adaptive, multicenter, randomized, double-blind, placebo-controlled, seamless phase 1/2/3 clinical trial in hospitalized patients with Covid-19 (clinicaltrials.gov: NCT04426695). Hospitalized patients > 18 years of age with a SARSCoV2-positive test result $<72$ hours, and symptom onset $<7$ days before randomization, were randomized 1:1:1 to receive placebo, $2.4 \mathrm{~g}(1.2 \mathrm{~g}$ each of casirivimab and imdevimab) or $8.0 \mathrm{~g}$ (4.0 g each of casirivimab and imdevimab). The primary clinical endpoint was the the incidence of death or required mechanical ventilation through Day 29. For the present work, 968 nasopharyngeal, 249 nasal and 119 saliva samples retrieved from a total of 272 patients were analyzed.

\section{Virus RNA, RT-PCR and Sequencing}

Viral RNA was extracted from hamster samples and from samples collected in the clinical trials (Viracor-Eurofins, MO, USA). RNAlater Stabilization Solution was aspirated from sample storage tubes, and 1-5mL Qiazol Lysis Reagent (Qiagen, \#79306) was added. Tissues were homogenized in Qiazol using an Omni International Prep 96 Homogenizer. The resulting lysate was stored overnight at -20C. In preparation for extraction, lysates were thawed, vortexed, and set up on the deck of a Hamilton Robotics Microlab STAR. The STAR dispensed 150uL of chloroform (Sigma Aldrich, \#C2432-500mL) per well to a $2 \mathrm{~mL}$ deep well plate (Life Technologies, \#4388476), followed by the addition of either 375 or $750 \mathrm{uL}$ of lysate. Additional Qiazol was added to wells where only $375 \mathrm{uL}$ lysate was added to bring the total volume of lysate to $750 \mathrm{uL}$. Robotic 96-channel pipetting was used to mix the Qiazol and chloroform layers in the deep well plate, followed by a 10 minute incubation at room temperature. The deep well plate was transferred off the STAR to a High Res Biosolutions NanoCell modular robotic system, then centrifuged for 10 minutes at 18G. The plate was returned to the STAR, and using robotic 96-channel pipetting, $400 \mu \mathrm{L}$ clear aqueous phase was aspirated from the top layer of the plate and transferred to a deep well plate containing $200 \mu \mathrm{L} 100 \%$ 
isopropanol and $10 \mu \mathrm{L}$ RNA binding beads from the MagMAX-96 for Microarrays Total RNA Isolation Kit (ThermoFisher, \#AM1839). The Nanocell system then transferred this plate to a connected KingFisher Flex. Total RNA was purified on the KingFisher Flex using the aforementioned MagMAX kit, according to manufacturer's specifications. 80uL of Qiagen RNase-Free DNase treatment (Qiagen, custom order) was substituted for the MagMAX kit DNase treatment. Once the purification was completed, the elution plate was transferred back to the STAR, and incubated on a Promega MagnaBot 96 Magnetic Separation Device for 5 minutes to remove residual RNA binding beads. The STAR then transferred $2 u L$ aliquots of the purified RNA to plates for the Unchained Labs Lunatic and Advanced Analytical Fragment Analyzer. The Lunatic plate reader was used to obtain concentration and purity data $\left(A_{260} / A_{280}, A_{260} / A_{230}\right)$, and the Fragment Analyzer was run with a Standard Sensitivity RNA Analysis Kit (Advanced Analytical, \#DNF-471-1000) for RNA quality data (RQN, 28s:18s, and DV200 scores). The remaining RNA was transferred using robotic 96-channel pipetting to a FluidX 96-format rack and stored at $-80 \mathrm{C}$.

Qualitative and quantitative measurements of viral load were determined by quantitative RT-PCR,10 ul of RNA combined with 25 ng Human Universal Reference RNA (Agilent) was purified by PureBeads (Roche Sequencing). cDNA synthesis was performed using SuperScript ${ }^{\mathrm{TM}}$ IV First-Strand Synthesis System (Thermal Fisher) following vendor's protocol. Then one half of cDNA (10 ul) was used to generate libraries using Swift Normalase $^{\text {TM }}$ Amplicon Panel (SNAP) SARS-CoV-2 Panel (Swift Biosciences) following vendor's protocol. Sequencing was run on NextSeq (Illumina) by multiplexed pairedread run with 2 X150 cycles. Overall quality report was generated summarizing the quality of all reads in each sample, along each base pair.

\section{Variant calling analysis}

Swift amplicon bulk RNA-seq reads were aligned to the SARS-COV-2 reference genome Wuhan-Hu-1 (accession: MN908947) using Minimap2 (v2.17)(Li, 2018). The alignments were sorted by read name, and primers were clipped by the complementary Swiftbiosciences primerclip software (v0.3.8) 
(https://github.com/swiftbiosciences/primerclip). Duplicate reads were removed using the Picard package (https://github.com/broadinstitute/picard) and target coverage was summarized for each sample with custom scripts. GATK HaplotypeCaller (v4.1.8) (McKenna et al., 2010) was used to perform single nucleotide polymorphism (SNP) calling. At each SNP, the frequency of viral mutations inferred from the sequencing reads were calculated from samtools (v1.9) pileup output(Li et al., 2009) . Variants were flagged if nucleotide positions were covered by at least 10 reads and frequency of mutated reads at these positions was at least $15 \%$.

\section{Variant Calling from SARS-CoV-2 Public Genomes}

Variant calling from SARS-CoV-2 public genomes was performed as previously described (Baum, 2020). SARS-CoV-2 complete genome sequences were downloaded from GISAID Nucleotide database (https://www.gisaid.org) on February 4th, 2021. Sequences were curated and genetic diversity of the spike-encoding gene was assessed across high quality genome sequences using custom pipelines. In brief, Blastn was used to align the Wuhan-Hu-1 spike nucleotide sequence (accession: MN908947) against each individual genome. Results were analyzed and presence of the gene was validated if alignment length was greater than $95 \%$ with an identity percentage greater than $70 \%$. Homologous spike protein sequences were extracted, translated and aligned to identify amino-acid changes with respect to the reference.

\section{Model of RBD-REGN10985-REGN10933-REGN10987}

The cryoEM structure of RBD-REGN10933-REGN10987 PDB (6XDG) and the cryoEM structure of RBD-REGN10989-REGN10985 (Fig S4) were superimposed using the software Pymol with the command align for the RBD, where only REGN10933, REGN10987 and REGN10985 are shown.

\section{Cryo-EM sample preparation and data collection}

Fab fragments of REGN10985 and REGN10989 antibodies were digested with FabALACTICA kit (Genovis) and purified by size-exclusion chromatography. $400 \mu \mathrm{g}$ of 
the REGN10985 Fab and $400 \mu \mathrm{g}$ of REGN10989 Fab were mixed with $200 \mu \mathrm{g}$ of SARSCoV-2 RBD and incubated on ice for $\sim 30$ min before being injected into a Superdex 200 increase gel filtration column equilibrated to $50 \mathrm{mM}$ Tris $\mathrm{pH} 7.5,150 \mathrm{mM} \mathrm{NaCl}$. Peak fractions containing the REGN10985 Fab - REGN10989 Fab - RBD complex were collected and concentrated using a $10 \mathrm{kDa}$ MWCO centrifugal filter (Amicon). For cryoEM grid preparation, the protein sample was diluted to $\sim 1.5 \mathrm{mg} / \mathrm{mL}$ and $0.15 \% \mathrm{PMAL}$ C8 amphipol was added. $3.5 \mu \mathrm{L}$ of protein was deposited onto a freshly plasma cleaned UltrAufoil grid (1.2/1.3, 300 mesh). Excess solution was blotted away with filter paper for $4 \mathrm{~s}$ at blotting force 0 , and plunge frozen into liquid ethane using a Vitrobot Mark IV (Thermo Fisher). The grid was loaded into a Titan Krios (Thermo Fisher) equipped with a K3 detector (Gatan) and 7,763 movies were collected using EPU (Thermo Fisher) at $105,000 x$ magnification, corresponding to a pixel size of $0.85 \AA$. A dose rate of 15 electrons per pixel per second was used and each movie was 2 seconds, corresponding to a total dose of $\sim 40$ electrons per $\AA 2$.

\section{Cryo-EM data processing}

All cryo-EM data processing was carried out using cryoSPARC v2.14.21(Punjani et al., 2017). The movies were aligned using patch motion correction and patch CTF estimation. An initial set of particles picked using blob picker were subjected to $2 \mathrm{D}$ classification to generate templates for template picking. $\sim 5.5$ million particles picked by template picking were subjected to multiple rounds of 2D classification to remove unbound Fabs and particles containing an incomplete complex, resulting in 607,309 'good' complex particles. Ab initio reconstruction with 6 classes generated a single class containing 146,054 particles that corresponded to the full REGN10985 Fab REGN10989 Fab - RBD complex. Non-uniform refinement of the particles in this class followed by local refinement resulted in a $3.3 \AA$ resolution $(F S C=0.143)$ map that was used for model building. Into this map, we manually placed models of the RBD (taken from PDB code 6M17) and the two Fabs (taken from prior Regeneron antibody structures). These models were then manually rebuilt using Coot and real-space refined against the map using Phenix(Emsley et al., 2010; Liebschner et al., 2019).

\section{ADDITIONAL RESOURCES}


bioRxiv preprint doi: https://doi.org/10.1101/2021.03.10.434834; this version posted May 26, 2021. The copyright holder for this preprint (which

was not certified by peer review) is the author/funder, who has granted bioRxiv a license to display the preprint in perpetuity. It is made available under aCC-BY-NC-ND 4.0 International license.

clinicaltrials.gov: NCT04425629

clinicaltrials.gov: NCT04426695

KEY RESOURCES TABLE 


\section{References}

Baum, A., Fulton, B.O., Wloga, E., Copin, R., Pascal, K.E., Russo, V., Giordano, S., Lanza, K., Negron, N., Ni, M., et al. (2020a). Antibody cocktail to SARS-CoV-2 spike protein prevents rapid mutational escape seen with individual antibodies. Science 369, 1014-1018.

Baum, A., Ajithdoss, D., Copin, R., Zhou, A., Lanza, K., Negron, N., Ni, M., Wei, Y., Mohammadi, K., Musser, B., et al. (2020b). REGN-COV2 antibodies prevent and treat SARSCoV-2 infection in rhesus macaques and hamsters. Science 370, 1110-1115.

CDC (2021). SARS-CoV-2 Variant Classifications and Definitions.

Davies, N.G., Jarvis, C.I., Group, C.C.-19 W., Edmunds, W.J., Jewell, N.P., Diaz-Ordaz, K., and Keogh, R.H. (2021). Increased mortality in community-tested cases of SARS-CoV-2 lineage B.1.1.7. Medrxiv Prepr Serv Heal Sci.

Dong, J., Zost, S.J., Greaney, A.J., Starr, T.N., Dingens, A.S., Chen, E.C., Chen, R.E., Case, J.B., Sutton, R.E., Gilchuk, P., et al. (2021). Genetic and structural basis for recognition of SARSCoV-2 spike protein by a two-antibody cocktail. Biorxiv 2021.01.27.428529.

Emsley, P., Lohkamp, B., Scott, W.G., and Cowtan, K. (2010). Features and development of Coot. Acta Crystallogr Sect D Biological Crystallogr 66, 486-501.

FDA (2021). FACT SHEET FOR HEALTH CARE PROVIDERS EMERGENCY USE AUTHORIZATION (EUA) OF BAMLANIVIMAB.

Garcia-Beltran, W.F., Lam, E.C., Denis, K.St., Nitido, A.D., Garcia, Z.H., Hauser, B.M., Feldman, J., Pavlovic, M.N., Gregory, D.J., Poznansky, M.C., et al. (2021). Multiple SARS$\mathrm{CoV}-2$ variants escape neutralization by vaccine-induced humoral immunity. Cell.

Greaney, A.J., Starr, T.N., Barnes, C.O., Weisblum, Y., Schmidt, F., Caskey, M., Gaebler, C., Agudelo, M., Finkin, S., Wang, Z., et al. (2021). Mutational escape from the polyclonal antibody response to SARS-CoV-2 infection is largely shaped by a single class of antibodies. BioRxiv.

Hansen, J., Baum, A., Pascal, K.E., Russo, V., Giordano, S., Wloga, E., Fulton, B.O., Yan, Y., Koon, K., Patel, K., et al. (2020). Studies in humanized mice and convalescent humans yield a SARS-CoV-2 antibody cocktail. Science 369, 1010-1014.

HHS (2021a). Update on COVID-19 variants and impact on bamlanivimab distribution. Https://Www.Phe.Gov/Emergency/Events/COVID19/InvestigationMCM/Bamlanivimab/Pages/Default.Aspx.

HHS (2021b). Bamlanivimab/etesevimab May 21, 2021: IMPORTANT UPDATE. Https://Www.Phe.Gov/Emergency/Events/COVID19/Investigation-MCM/BamlanivimabEtesevimab/Pages/Default.Aspx. 
Jones, B.E., Brown-Augsburger, P.L., Corbett, K.S., Westendorf, K., Davies, J., Cujec, T.P., Wiethoff, C.M., Blackbourne, J.L., Heinz, B.A., Foster, D., et al. (2021). The neutralizing antibody, LY-CoV555, protects against SARS-CoV-2 infection in nonhuman primates. Sci Transl Med 13, eabf1906.

Lawson, N.D., Stillman, E.A., Whitt, M.A., and Rose, J.K. (1995). Recombinant vesicular stomatitis viruses from DNA. Proceedings of the National Academy of Sciences of the United States of America 92, 4477-4481.

Li, H. (2018). Minimap2: pairwise alignment for nucleotide sequences. Bioinformatics 34, 30943100 .

Li, H., Handsaker, B., Wysoker, A., Fennell, T., Ruan, J., Homer, N., Marth, G., Abecasis, G., Durbin, R., and Subgroup, 1000 Genome Project Data Processing (2009). The Sequence Alignment/Map format and SAMtools. Bioinformatics 25, 2078-2079.

Liebschner, D., Afonine, P.V., Baker, M.L., Bunkóczi, G., Chen, V.B., Croll, T.I., Hintze, B., Hung, L.-W., Jain, S., McCoy, A.J., et al. (2019). Macromolecular structure determination using $\mathrm{X}$ - rays, neutrons and electrons: recent developments in Phenix. Acta Crystallogr Sect D 75, 861-877.

Liu, L., Wang, P., Nair, M.S., Yu, J., Rapp, M., Wang, Q., Luo, Y., Chan, J.F.-W., Sahi, V., Figueroa, A., et al. (2020). Potent neutralizing antibodies against multiple epitopes on SARSCoV-2 spike. Nature 584, 450-456.

Liu, Y., Liu, J., Xia, H., Zhang, X., Fontes-Garfias, C.R., Swanson, K.A., Cai, H., Sarkar, R., Chen, W., Cutler, M., et al. (2021a). Neutralizing Activity of BNT162b2-Elicited Serum. New Engl J Med 384, 1466-1468.

Liu, Z., VanBlargan, L.A., Bloyet, L.-M., Rothlauf, P.W., Chen, R.E., Stumpf, S., Zhao, H., Errico, J.M., Theel, E.S., Liebeskind, M.J., et al. (2021b). Identification of SARS-CoV-2 spike mutations that attenuate monoclonal and serum antibody neutralization. Cell Host Microbe.

Madhi, S.A., Baillie, V., Cutland, C.L., Voysey, M., Koen, A.L., Fairlie, L., Padayachee, S.D., Dheda, K., Barnabas, S.L., Bhorat, Q.E., et al. (2021). Efficacy of the ChAdOx1 nCoV-19 Covid-19 Vaccine against the B.1.351 Variant. New Engl J Med.

McKenna, A., Hanna, M., Banks, E., Sivachenko, A., Cibulskis, K., Kernytsky, A., Garimella, K., Altshuler, D., Gabriel, S., Daly, M., et al. (2010). The Genome Analysis Toolkit: A MapReduce framework for analyzing next-generation DNA sequencing data. Genome Res 20, 1297-1303.

Nonaka, C.K.V., Franco, M.M., Gräf, T., Barcia, C.A. de L., Mendonça, R.N. de Á., Sousa, K.A.F. de, Neiva, L.M.C., Fosenca, V., Mendes, A.V.A., Aguiar, R.S. de, et al. (2021). Genomic Evidence of SARS-CoV-2 Reinfection Involving E484K Spike Mutation, Brazil - Volume 27, 
Number 5-May 2021 - Emerging Infectious Diseases journal - CDC. Emerg Infect Dis 27, $1522-1524$.

Pascal, K.E., Dudgeon, D., Trefry, J.C., Anantpadma, M., Sakurai, Y., Murin, C.D., Turner, H.L., Fairhurst, J., Torres, M., Rafique, A., et al. (2018). Development of Clinical-Stage Human Monoclonal Antibodies That Treat Advanced Ebola Virus Disease in Nonhuman Primates. The Journal of Infectious Diseases 218, S612-S626.

Pinto, D., Park, Y.-J., Beltramello, M., Walls, A.C., Tortorici, M.A., Bianchi, S., Jaconi, S., Culap, K., Zatta, F., Marco, A.D., et al. (2020). Cross-neutralization of SARS-CoV-2 by a human monoclonal SARS-CoV antibody. Nature 583, 290-295.

Punjani, A., Rubinstein, J.L., Fleet, D.J., and Brubaker, M.A. (2017). cryoSPARC: algorithms for rapid unsupervised cryo-EM structure determination. Nat Methods 14, 290-296.

Shi, R., Shan, C., Duan, X., Chen, Z., Liu, P., Song, J., Song, T., Bi, X., Han, C., Wu, L., et al. (2020). A human neutralizing antibody targets the receptor-binding site of SARS-CoV-2. Nature $584,120-124$.

Starr, T.N., Greaney, A.J., Dingens, A.S., and Bloom, J.D. (2021). Complete map of SARSCoV-2 RBD mutations that escape the monoclonal antibody LY-CoV555 and its cocktail with LY-CoV016. Cell Reports Medicine 2, 100255.

Tegally, H., Wilkinson, E., Giovanetti, M., Iranzadeh, A., Fonseca, V., Giandhari, J., Doolabh, D., Pillay, S., San, E.J., Msomi, N., et al. (2020). Emergence and rapid spread of a new severe acute respiratory syndrome-related coronavirus 2 (SARS-CoV-2) lineage with multiple spike mutations in South Africa. MedRxiv.

Wang, P., Nair, M.S., Liu, L., Iketani, S., Luo, Y., Guo, Y., Wang, M., Yu, J., Zhang, B., Kwong, P.D., et al. (2021). Antibody Resistance of SARS-CoV-2 Variants B.1.351 and B.1.1.7. Nature 1-9.

Weinreich, D., Sivapalasingam, S., Norton, T.D., Ali, S., Gao, H., Bhore, R., Xiao, J., Hooper, A.T., Hamilton, J.D., Musser, B.J., et al. (2021). REGEN-COV Antibody Cocktail Clinical Outcomes Study in Covid-19 Outpatients. BioRxiv.

Weinreich, D.M., Sivapalasingam, S., Norton, T., Ali, S., Gao, H., Bhore, R., Musser, B.J., Soo, Y., Rofail, D., Im, J., et al. (2020). REGN-COV2, a Neutralizing Antibody Cocktail, in Outpatients with Covid-19. New Engl J Med.

Weisblum, Y., Schmidt, F., Zhang, F., DaSilva, J., Poston, D., Lorenzi, J.C., Muecksch, F., Rutkowska, M., Hoffmann, H.-H., Michailidis, E., et al. (2020). Escape from neutralizing antibodies by SARS-CoV-2 spike protein variants. Elife 9, e61312. 
West, A.P., Barnes, C.O., Yang, Z., and Bjorkman, P.J. (2021). SARS-CoV-2 lineage B.1.526 emerging in the New York region detected by software utility created to query the spike mutational landscape. BioRxiv.

Yurkovetskiy, L., Wang, X., Pascal, K.E., Tomkins-Tinch, C., Nyalile, T.P., Wang, Y., Baum, A., Diehl, W.E., Dauphin, A., Carbone, C., et al. (2020). Structural and Functional Analysis of the D614G SARS-CoV-2 Spike Protein Variant. Cell 183, 739-751.e8.

Zhang, W., Davis, B.D., Chen, S.S., Martinez, J.M.S., Plummer, J.T., and Vail, E. (2021). Emergence of a Novel SARS-CoV-2 Variant in Southern California. Jama 325, 1324-1326. 
bioRxiv preprint doi: https://doi.org/10.1101/2021.03.10.434834; this version posted May 26, 2021. The copyright holder for this preprint (which was not certified by peer review) is the author/funder, who has granted bioRxiv a license to display the preprint in perpetuity. It is made Figure 1

A

\section{D614G}

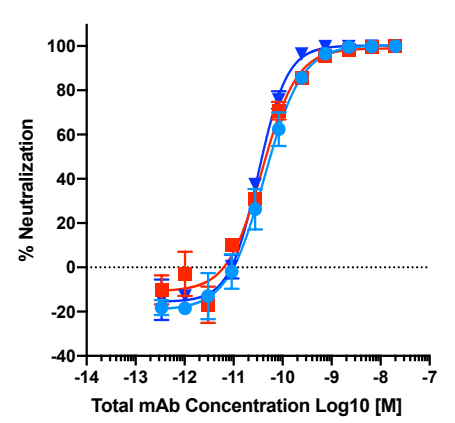

E484K (B.1.526 New York)

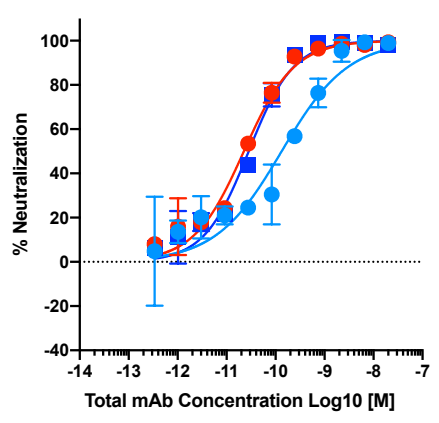

B.1.1.7 (UK)

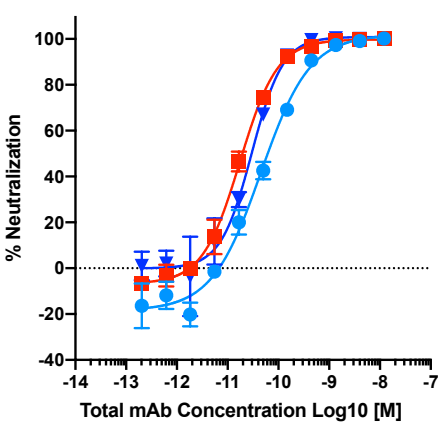

B.1.351 (South Africa)

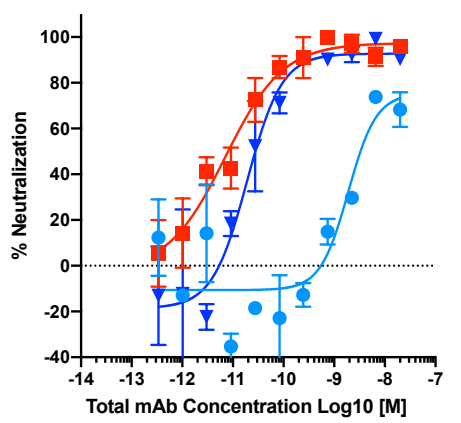

L452R (B.1.429 California)

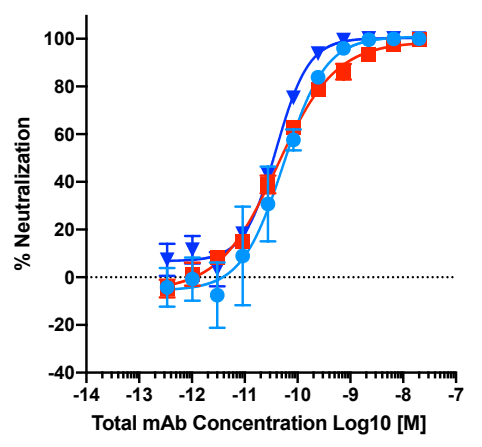

P.1 (Brazil)

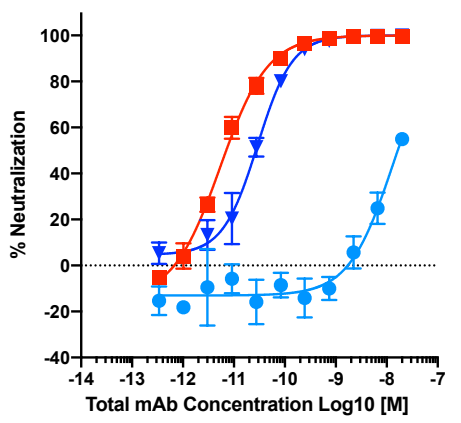

L452R/E484Q (B.1.617.1 India)

L452R/T478K (B.1.617.2 India)

B
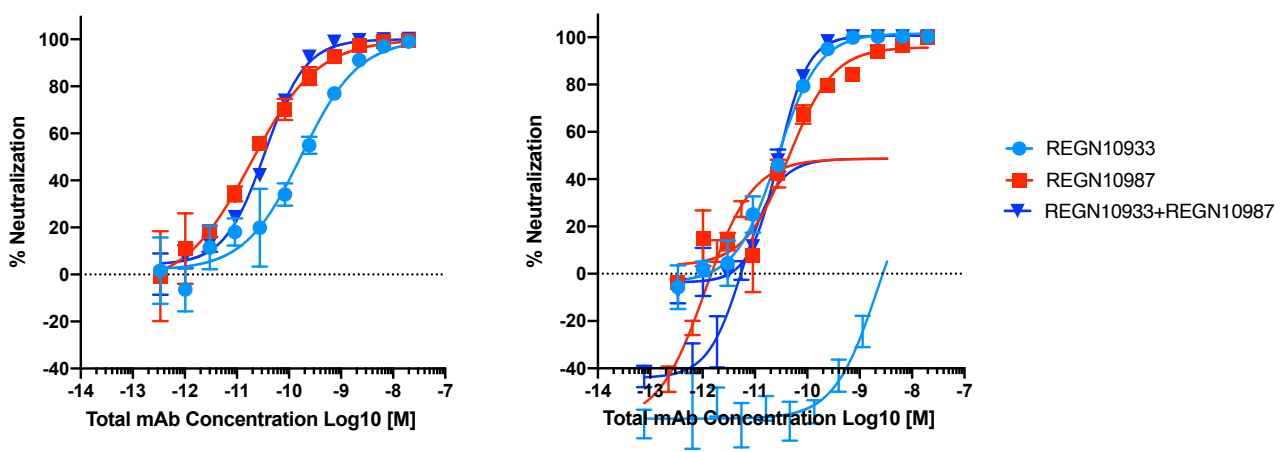

Fold decrease in IC50 from reference (D614G) pseudovirus

\begin{tabular}{c|c|c|c|}
\cline { 2 - 4 } Variant & REGN10933 & REGN10987 & $\begin{array}{c}\text { REGN10933+ } \\
\text { REGN10987 }\end{array}$ \\
\hline B.1.1.7 (UK) & 1.2 & 0.7 & 0.9 \\
\hline L452R (B.1.427/B.1.429 California) & 1.3 & 1.1 & 1.2 \\
\hline E484K (B.1.526 New York) & 15.0 & 1.2 & 1.6 \\
\hline B.1.351 (South Africa) & 44.7 & 0.2 & 0.6 \\
\hline P.1 (Brazil) & 417.6 & 0.1 & 1.7 \\
\hline L452R/E484Q (B.1.617.1 India) & 7.2 & 0.6 & 1.4 \\
\hline L452R/T478K (B.1.617.2 India) & 0.7 & 0.9 & 0.8 \\
\hline
\end{tabular}


bioRxiv preprint doi: https://doi.org/10.1101/2021.03.10.434834; this version posted May 26, 2021. The copyright holder for this preprint (which was not certified by peer review) is the author/funder, who has granted bioRxiv a license to display the preprint in perpetuity. It is made available under aCA-BY-NC-ND 4.0 International license.

Figure 2

A

\begin{tabular}{|c|c|c|c|c|c|c|c|c|c|c|c|c|}
\hline & P1 & P2 & P3 & P4 & P5 & P6 & P7 & P8 & P9 & P10 & P11 & \\
\hline REGN10933 & & & & & & & & & & & & \\
\hline REGN10985 & & & & & & & & & & & & \\
\hline REGN10987 & & & & & & & & & & & & \\
\hline REGN10933+REGN10987 & & & & & & & & & & & & \\
\hline $\begin{array}{c}\text { REGN10933+REGN10987 } \\
\text { +REGN10985 }\end{array}$ & & & & & & & & & & & & \\
\hline CB6 & & & & & & & & & & & & \\
\hline LY-CoV555 & & & & & & & & & & & & \\
\hline CB6+LY-CoV555 & & & & & & & & & & & & \\
\hline COV2-2130 & & & & & & & & & & & & \\
\hline COV2-2196 & & & & & & & & & & & & Complete Escape \\
\hline COV2-2130+COV2-2196 & & & & & & & & & & & & Partial Escape \\
\hline VIR-7831 & & & & & & & & & & & & No Escape \\
\hline
\end{tabular}

B

D614G

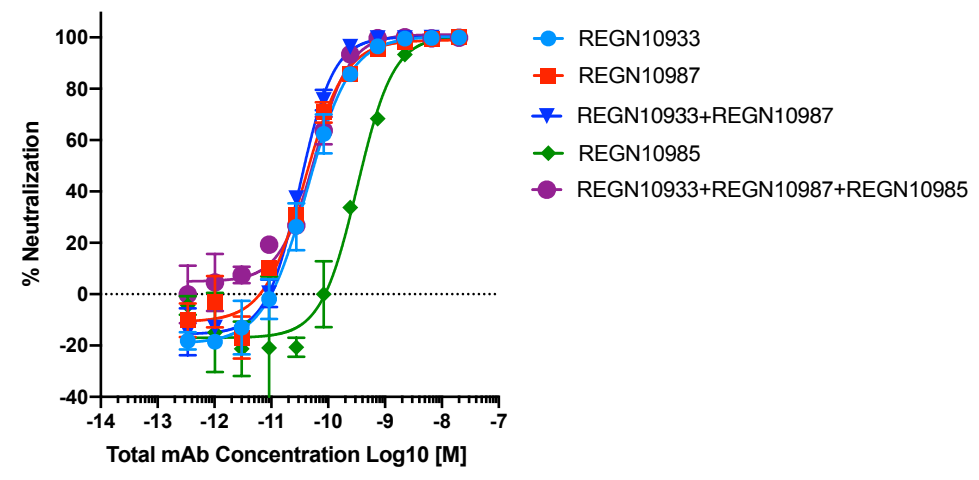

C

REGN10933
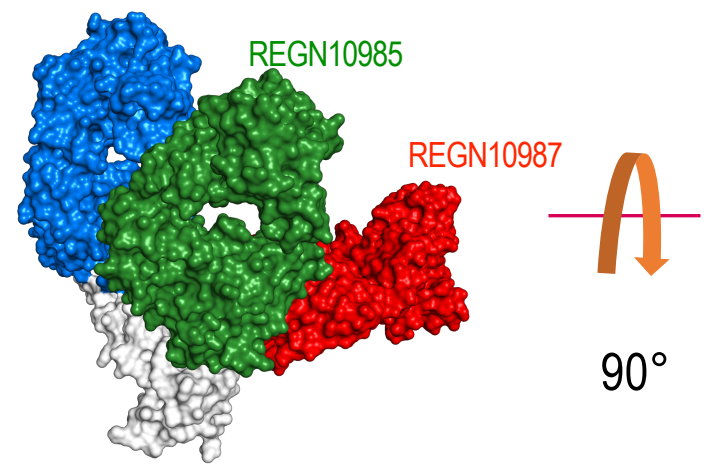

$90^{\circ}$

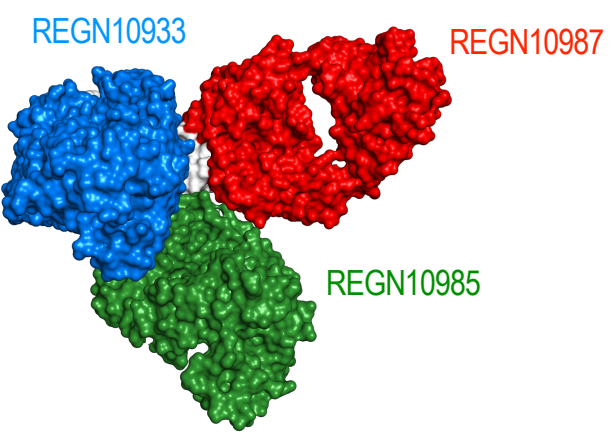

REGN10933
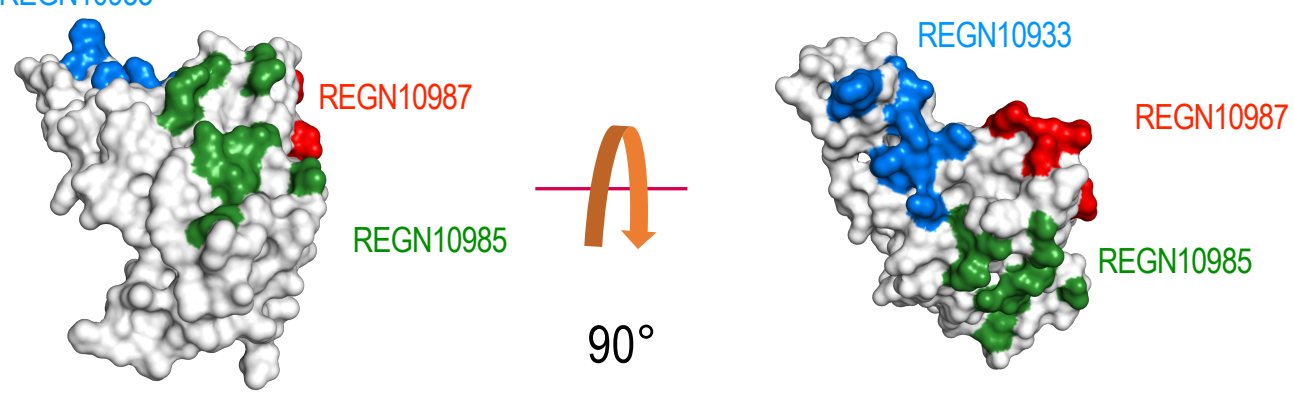
bioRxiv preprint doi: https://doi.org/10.1101/2021.03.10.434834; this version posted May 26, 2021. The copyright holder for this preprint (which was not certified by peer review) is the author/funder, who has granted bioRxiv a license to display the preprint in perpetuity. It is made available under ACC-BY-NC-ND 4.0 International license.

\section{Figure 3}

A

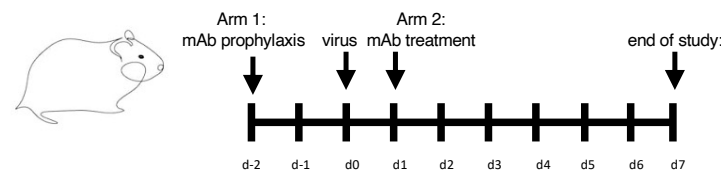

\begin{tabular}{c|c} 
Challenge route & intranasal \\
\hline Challenge dose & $1 \times 10^{\wedge} 4$ PFU WA isolate \\
\hline $\mathrm{mAb} / \mathrm{s}$ & REGN10933 \\
REGN10897 \\
REGN10933+REGN10987 \\
\hline doses & $50,5(\mathrm{mg} / \mathrm{kg})$ \\
\hline
\end{tabular}

B
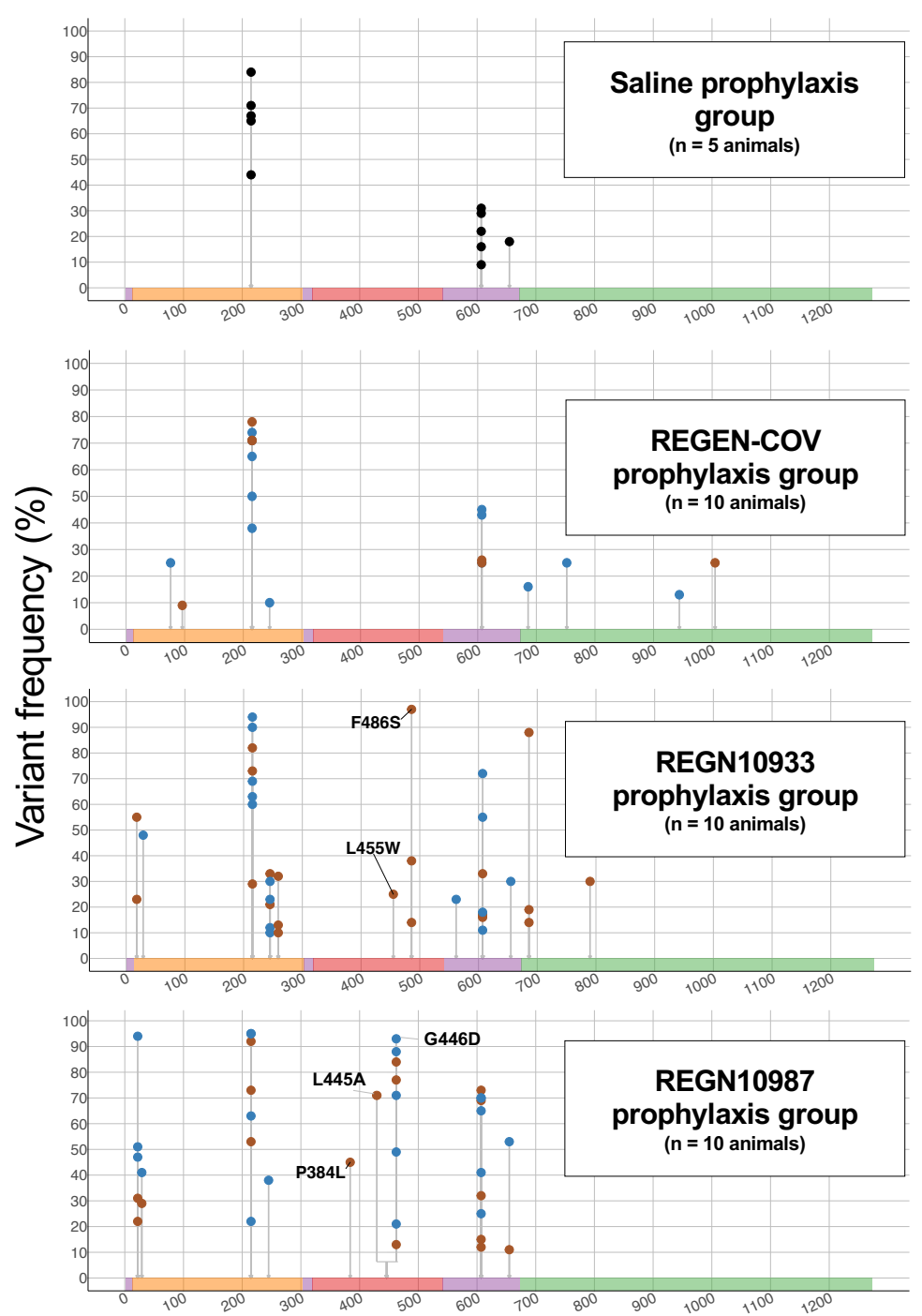

Amino acid position
C
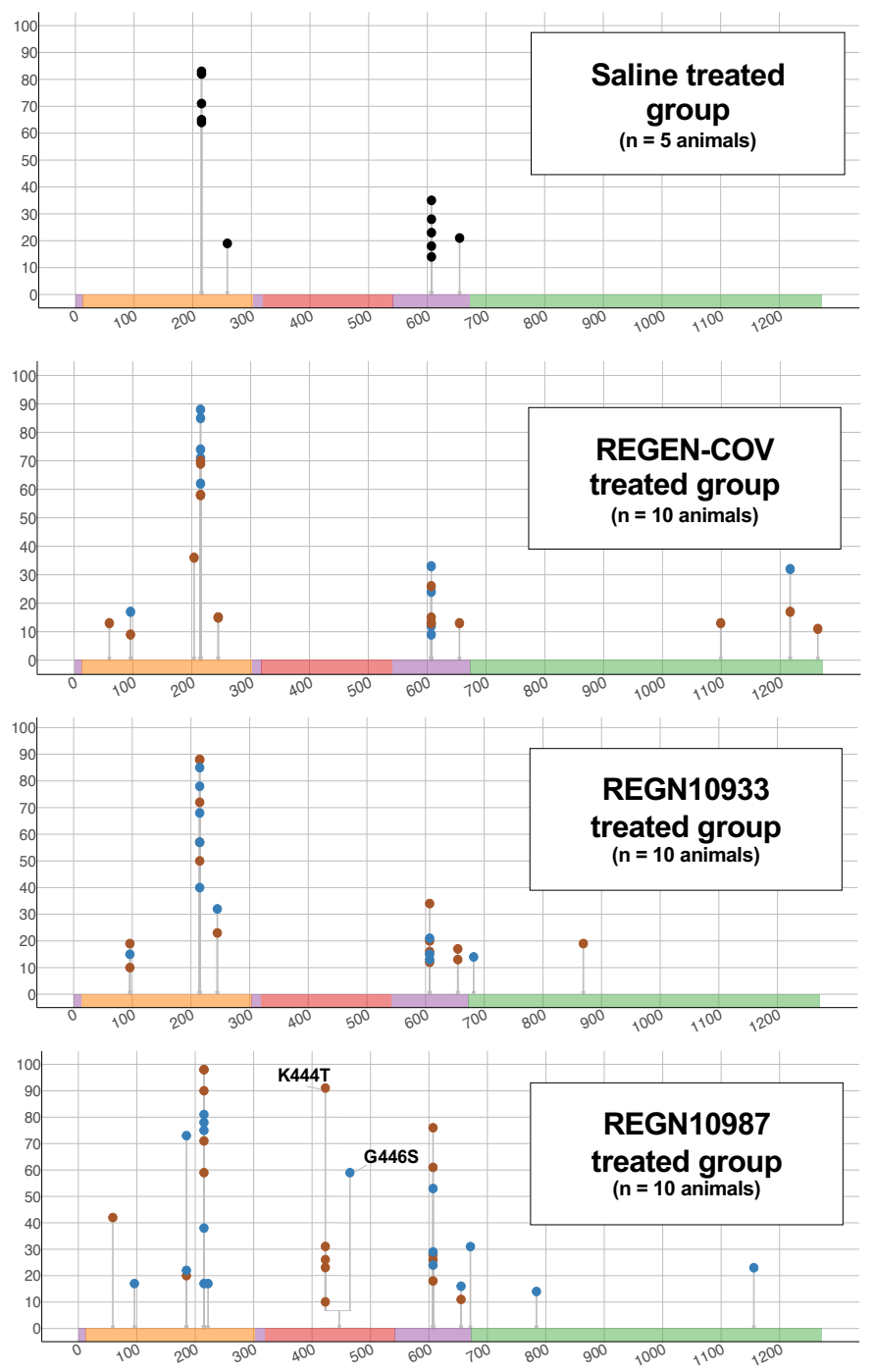

Amino acid position

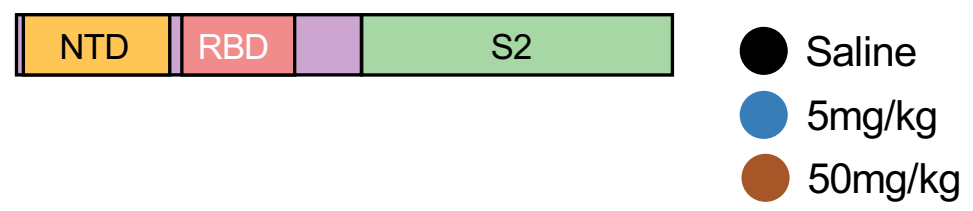


bioRxiv preprint doi: https://doi.org/10.1101/2021.03.10.434834; this version posted May 26, 2021. The copyright holder for this preprint (which was not certified by peer review) is the author/funder, who has granted bioRxiv a license to display the preprint in perpetuity. It is made available under aCC-BY-NC-ND 4.0 International license.

\section{Figure 4}

A Variants identified in 1 sample from at least 1 patient
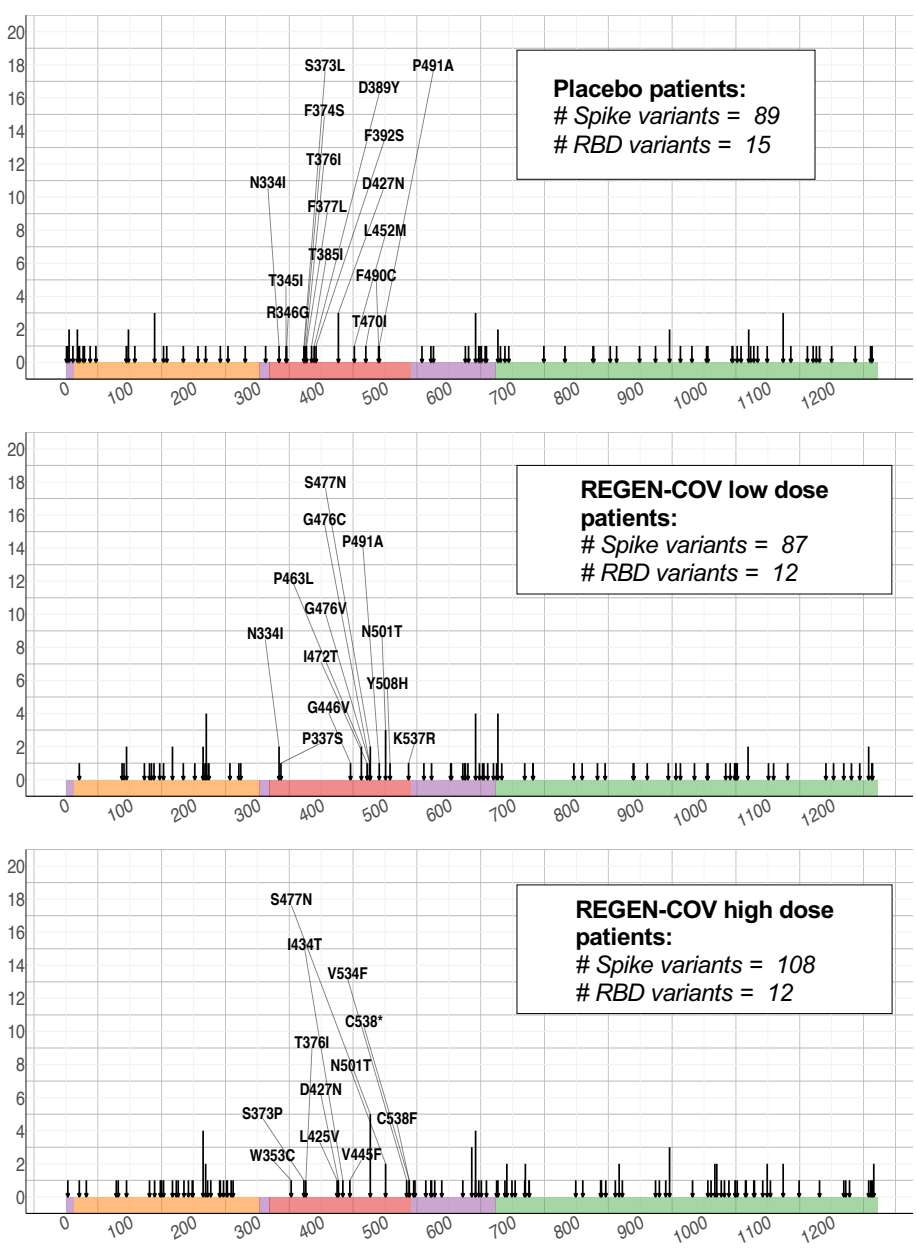

Amino acid position
B Variants identified in 2 samples from at least 1 patient.
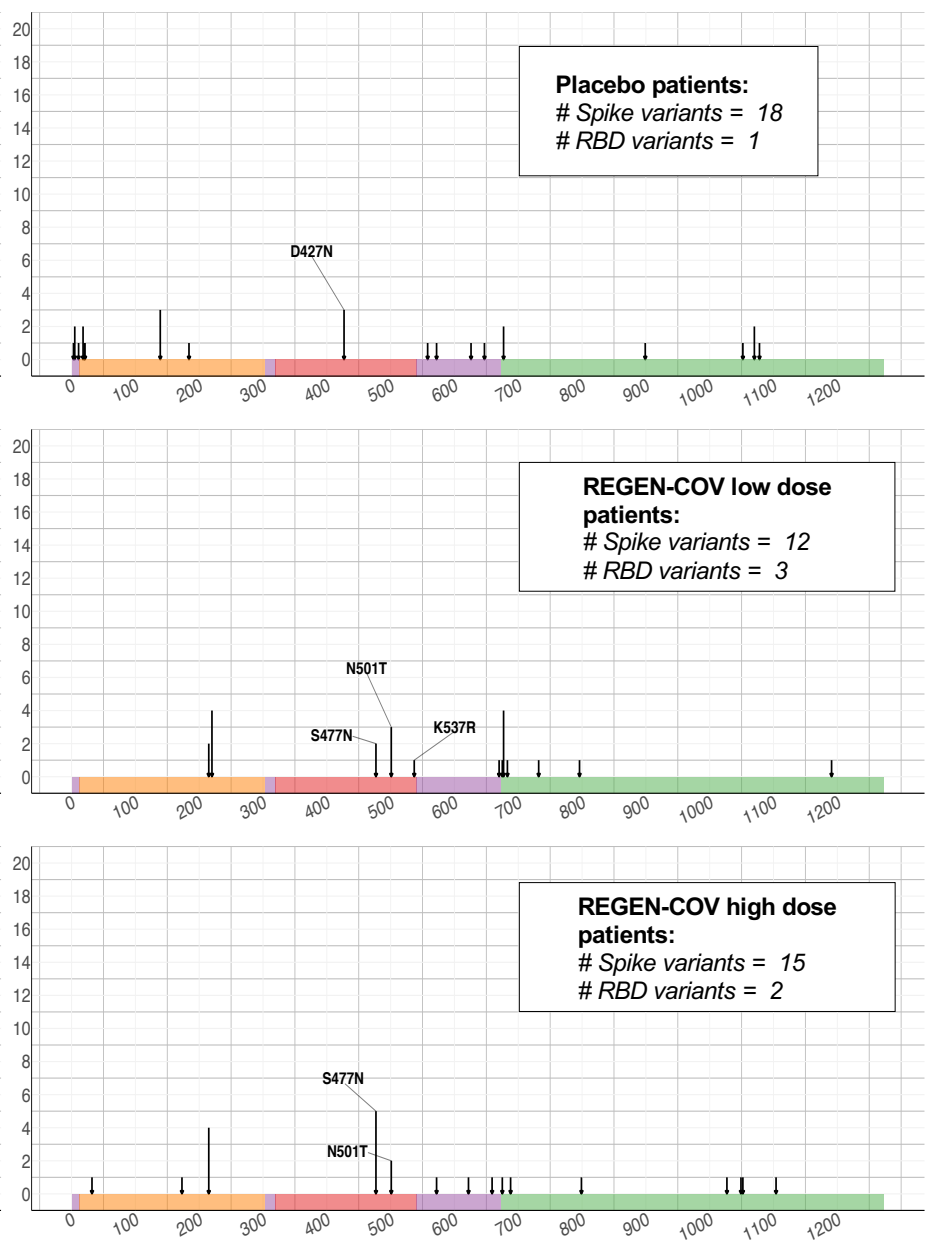

Amino acid position

\begin{tabular}{||l||l|l|l|}
\hline NTD & RBD & & S2 \\
\hline
\end{tabular}


bioRxiv preprint doi: https://doi.org/10.1101/2021.03.10.434834; this version posted May 26, 2021. The copyright holder for this preprint (which

was not certified by peer review) is the author/funder, who has granted bioRxiv a license to display the preprint in perpetuity. It is made available under aCC-BY-NC-ND 4.0 International license.

\section{Figure 5}

N501T

\section{REGEN-COV}
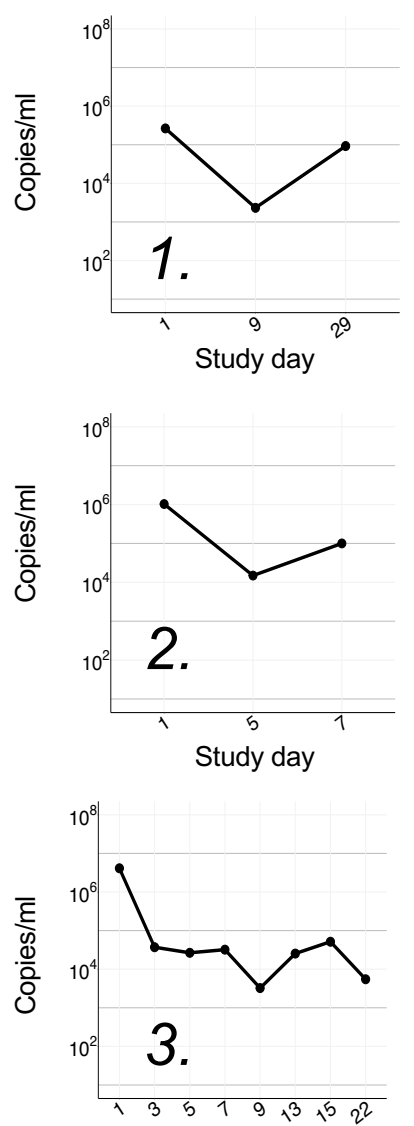

Study day
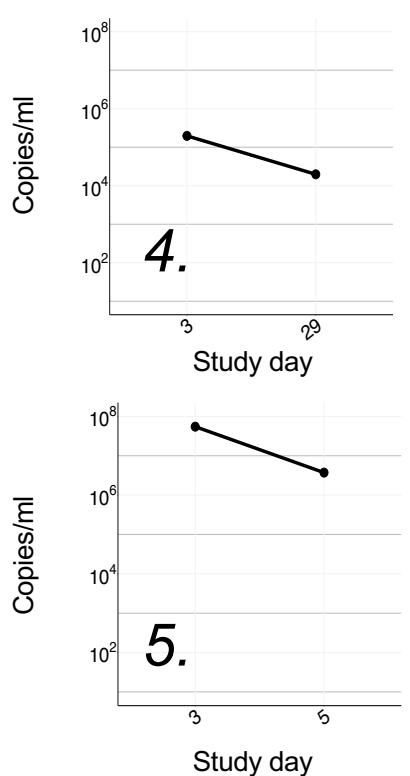

K537R

\section{REGEN-COV}
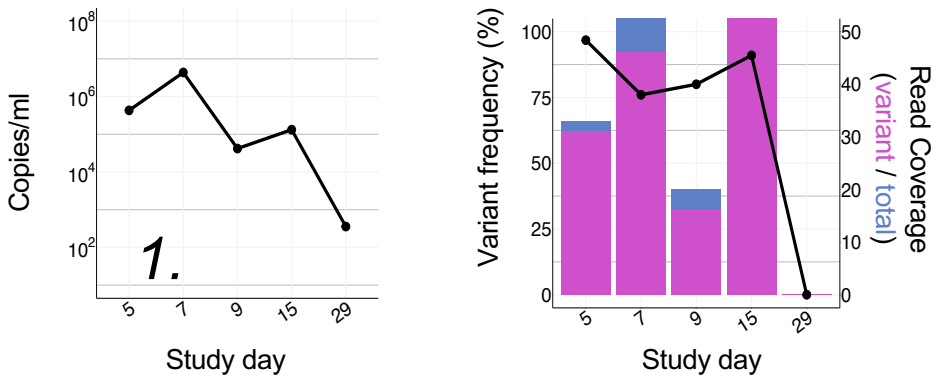
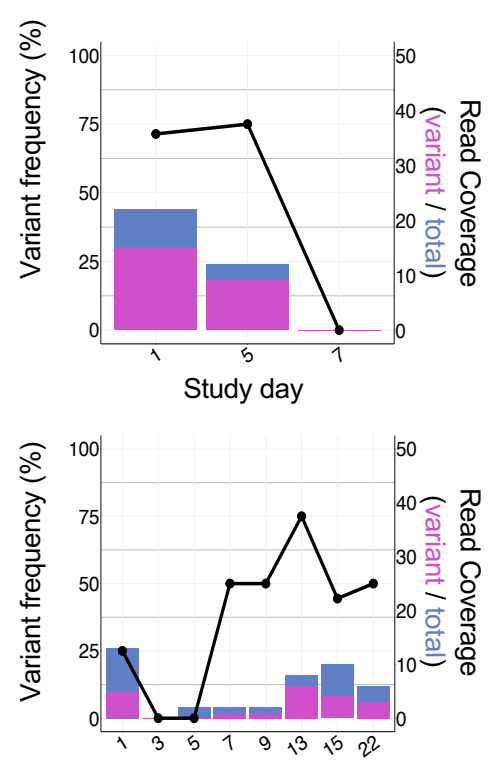

Study day
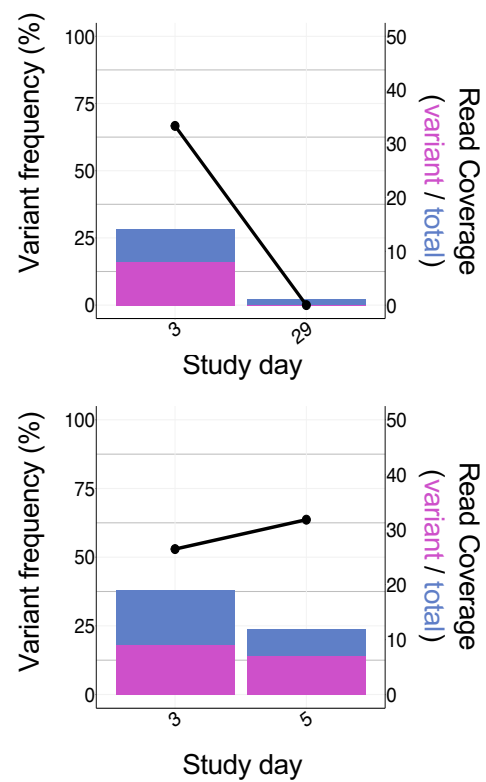
bioRxiv preprint doi: https://doi.org/10.1101/2021.03.10.434834; this version posted May 26, 2021. The copyright holder for this preprint (which was not certified by peer review) is the author/funder, who has granted bioRxiv a license to display the preprint in perpetuity. It is made available under aCC-BY-NC-ND 4.0 International license.

\section{Figure 6}

A

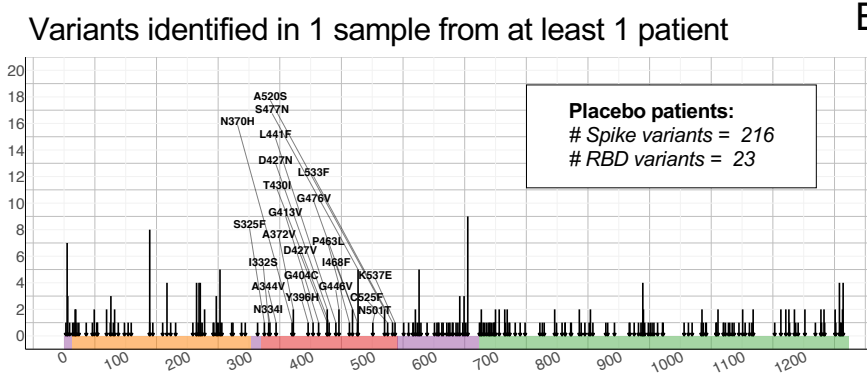

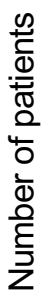
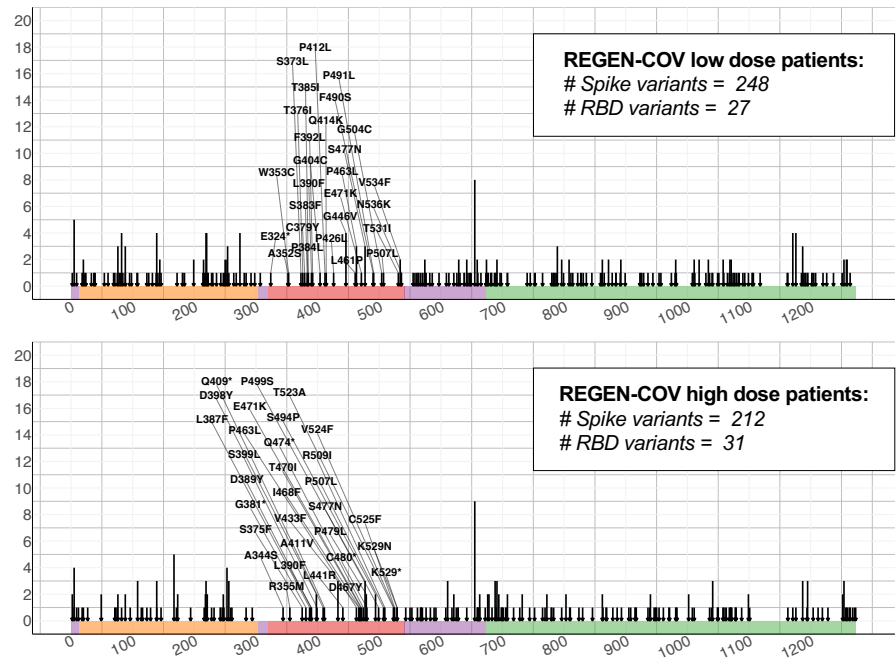

Amino acid position
B Variants identified in 2 samples from at least 1 patient.
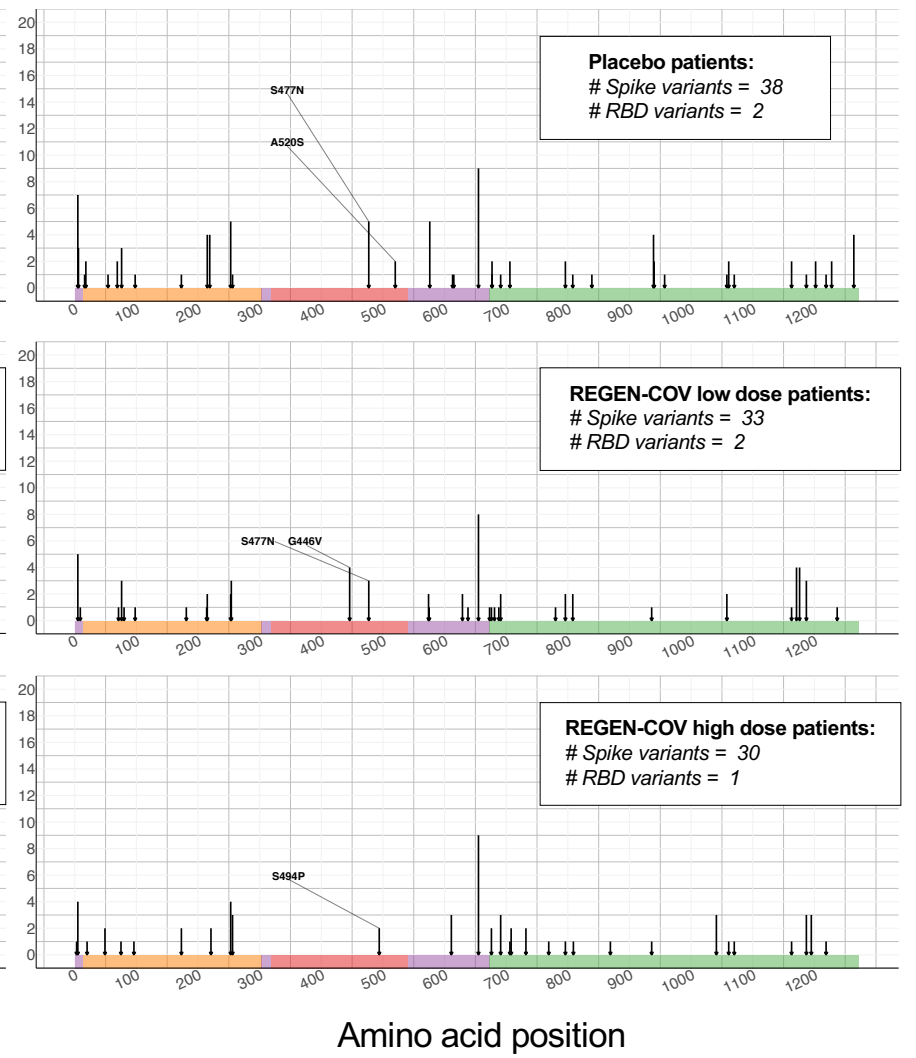

\begin{tabular}{||l||l|l|l|}
\hline NTD & RBD & & S2 \\
\hline
\end{tabular}


bioRxiv preprint doi: https://doi.org/10.1101/2021.03.10.434834; this version posted May 26, 2021. The copyright holder for this preprint (which was not certified by peer review) is the author/funder, who has granted bioRxiv a license to display the preprint in perpetuity. It is made available under aCC-BY-NC-ND 4.0 Iforgtipral dicepse.

\section{A S494P \\ REGEN-COV}
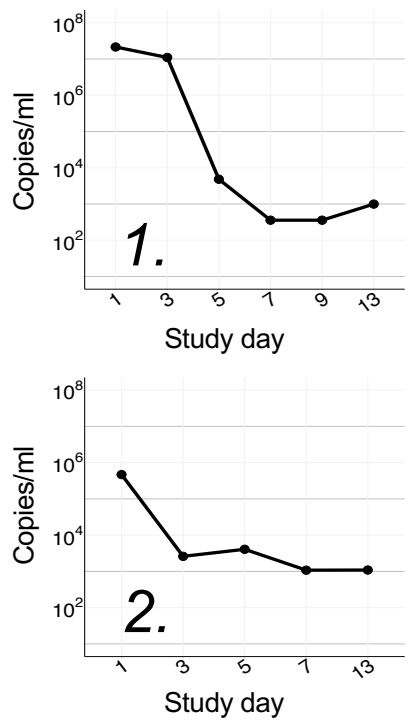

B
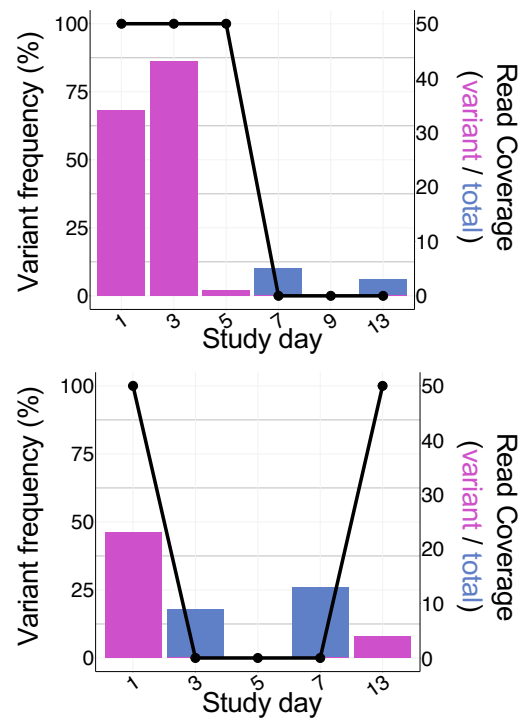

G446V

\section{REGEN-COV}
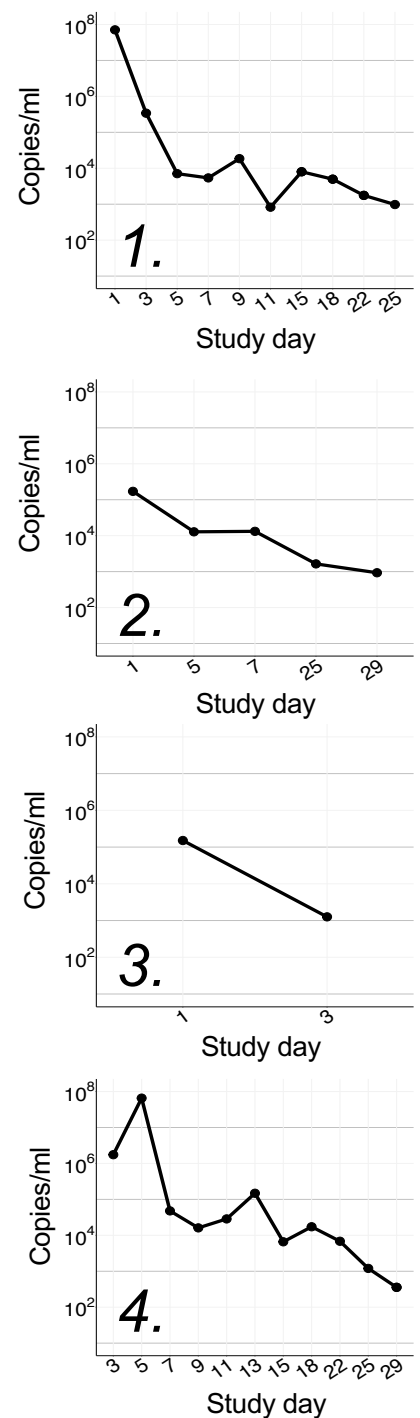
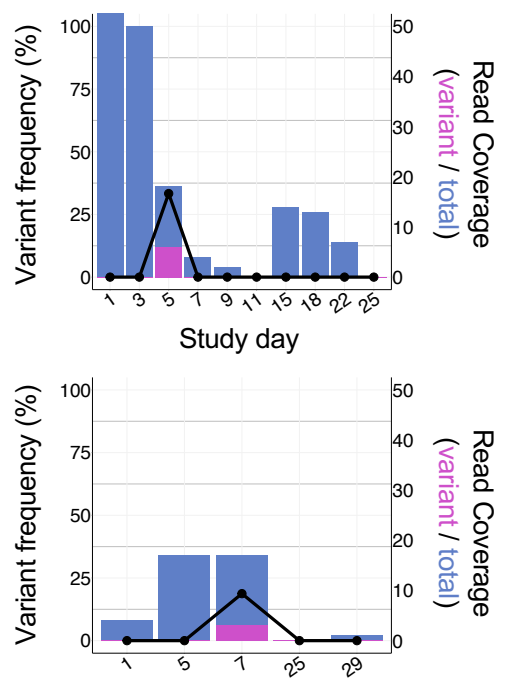

Study day
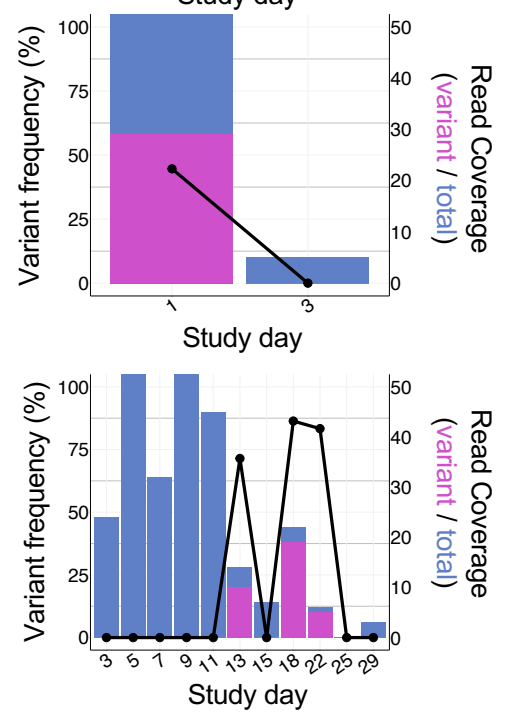

\section{Placebo}
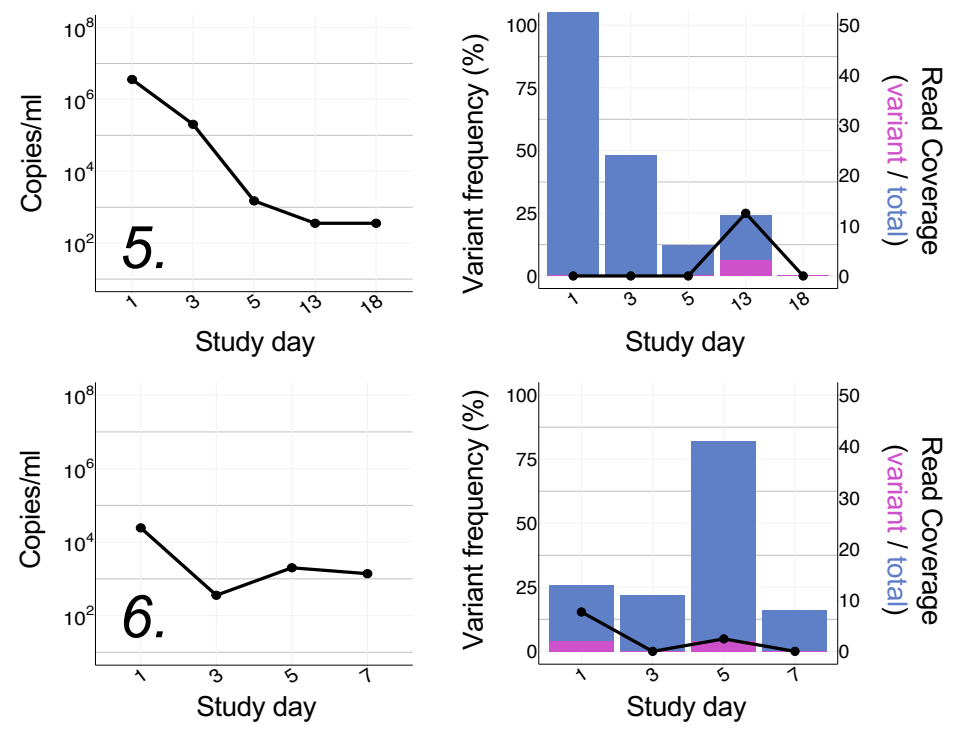
bioRxiv preprint doi: https://doi.org/10.1101/2021.03.10.434834; this version posted May 26, 2021. The copyright holder for this preprint (which was not certified by peer review) is the author/funder, who has granted bioRxiv a license to display the preprint in perpetuity. It is made

Figure $\mathbf{S 1}$

\section{S477N}

\section{REGEN-COV - hospitalized patients}
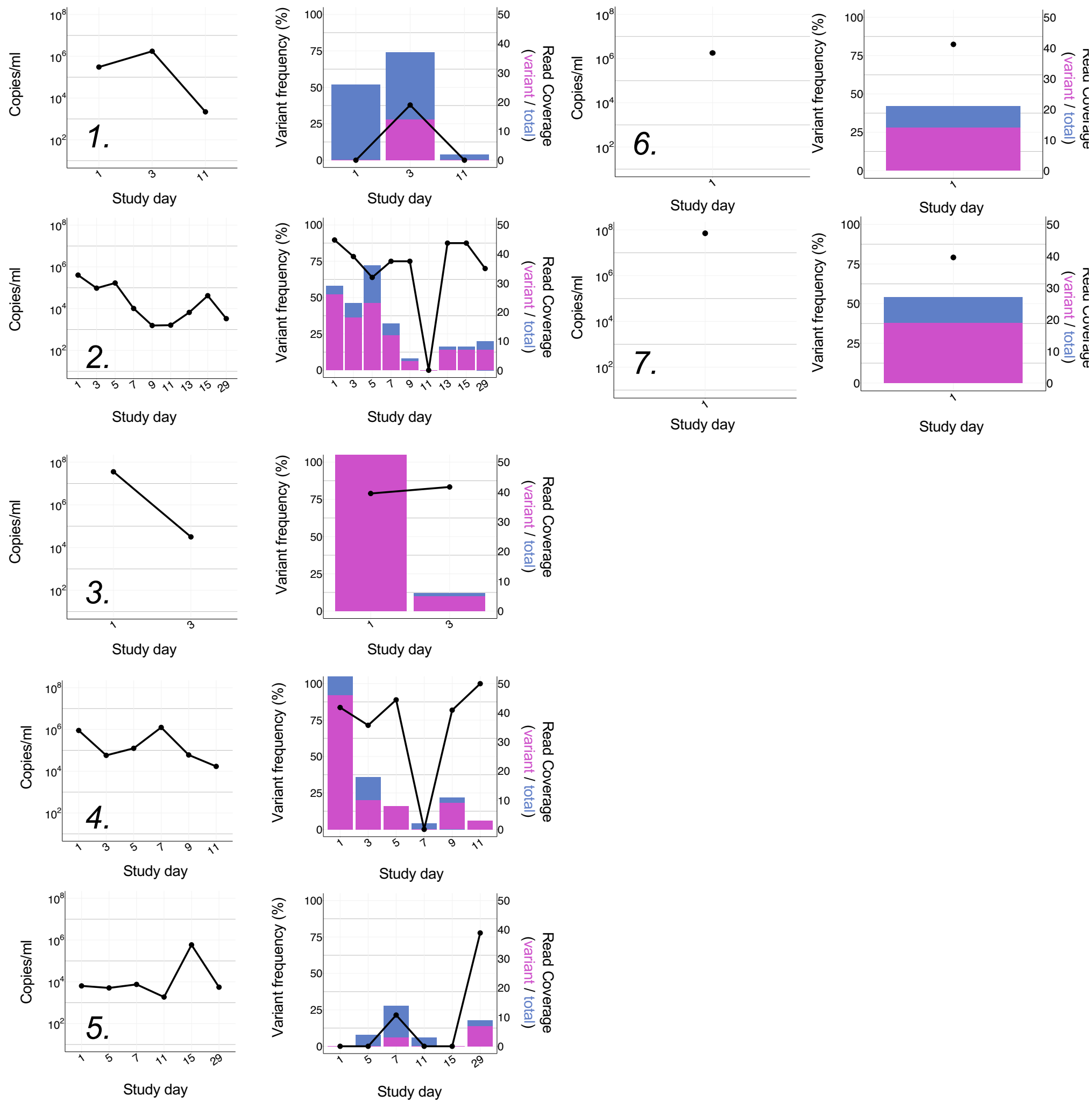

Study day 
bioRxiv preprint doi: https://doi.org/10.1101/2021.03.10.434834; this version posted May 26, 2021. The copyright holder for this preprint (which was not certified by peer review) is the author/funder, who has granted bioRxiv a license to display the preprint in perpetuity. It is made

Figure S2

\section{S477N}

\section{REGEN-COV - outpatients}
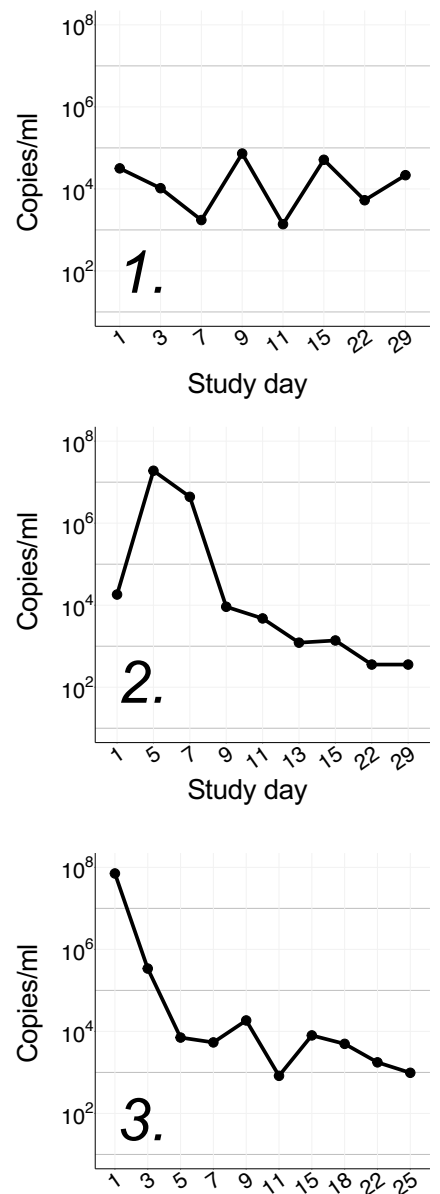
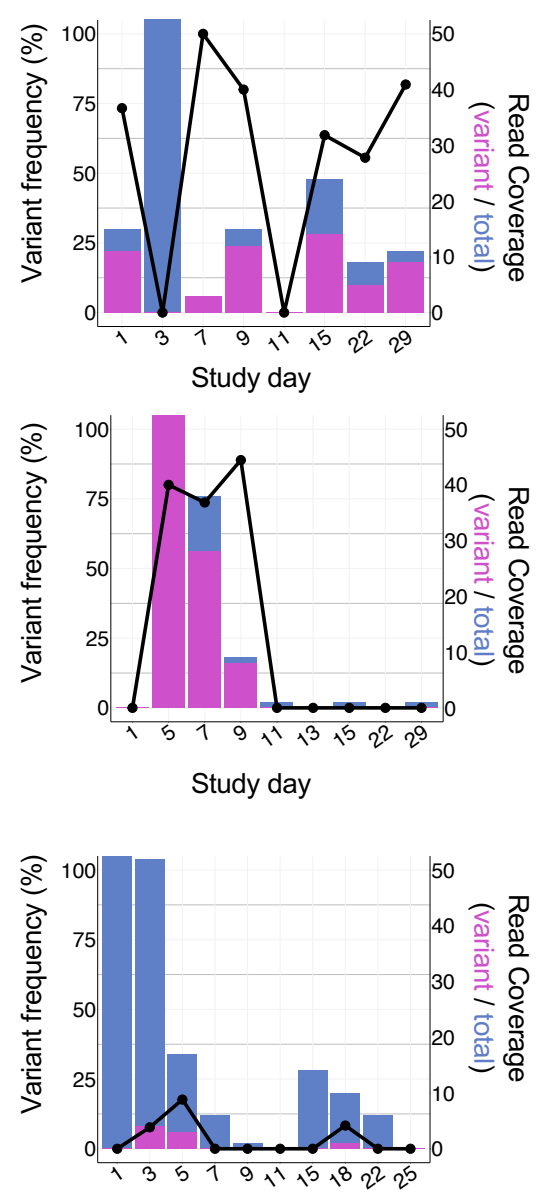

\section{Placebo - outpatients}
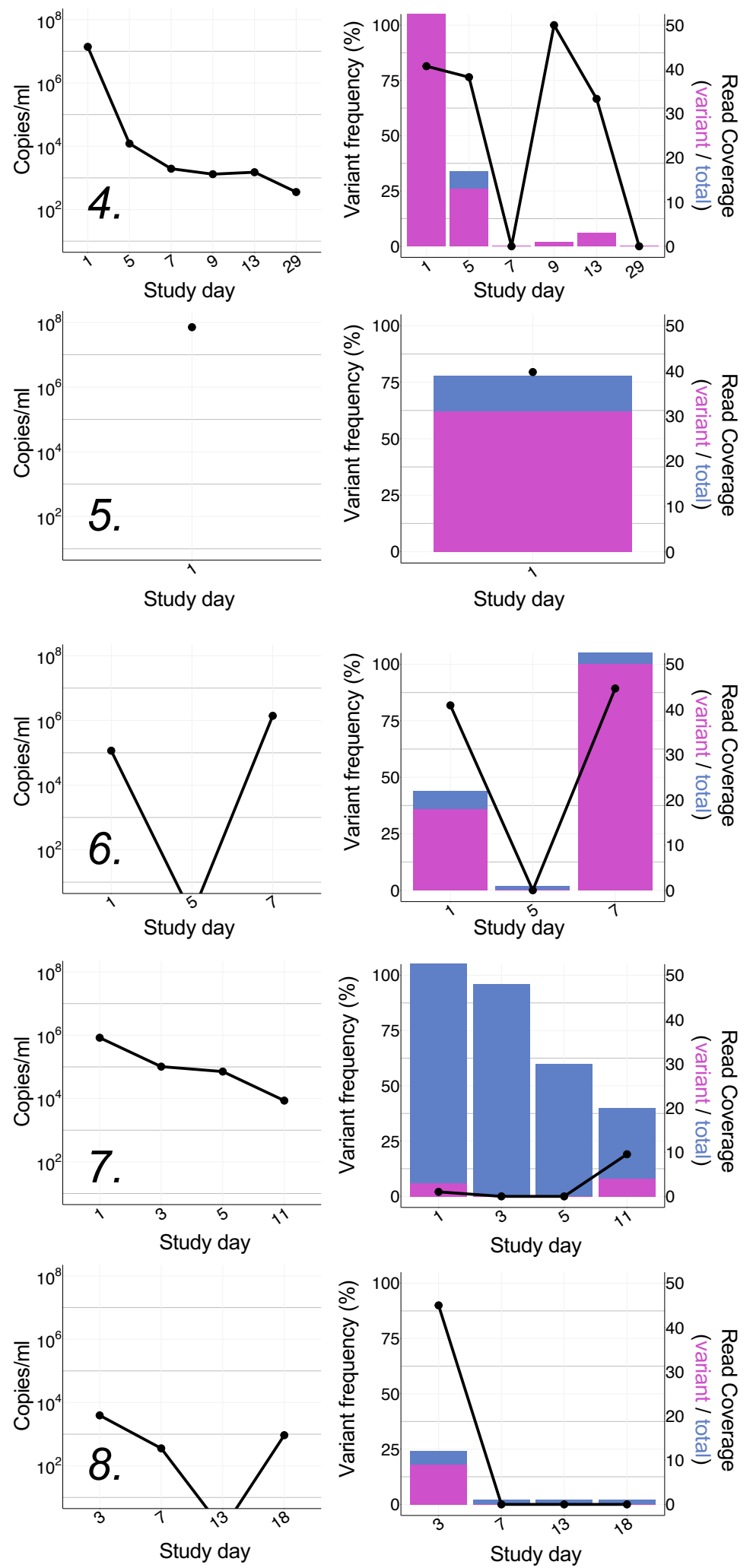
bioRxiv preprint doi: https://doi.org/10.1101/2021.03.10.434834; this version posted May 26, 2021. The copyright holder for this preprint (which was not certified by peer review) is the author/funder, who has granted bioRxiv a license to display the preprint in perpetuity. It is made available under aCC-BY-NC-ND 4.0 International license.

\section{Figure S3}

A

D614G

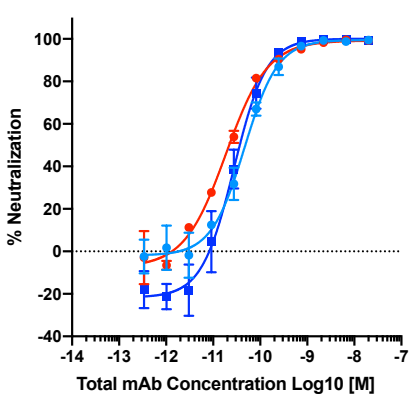

N501Y

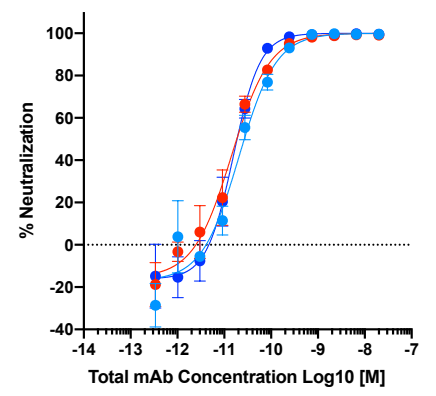

G446V

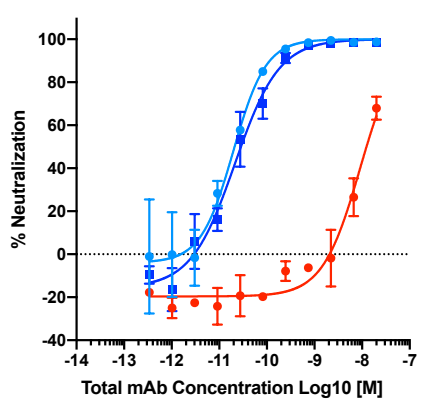

S494P

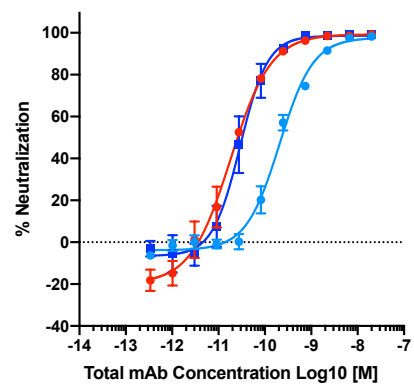

S477N

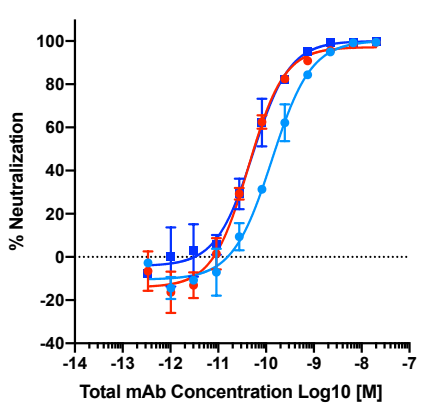

K537R

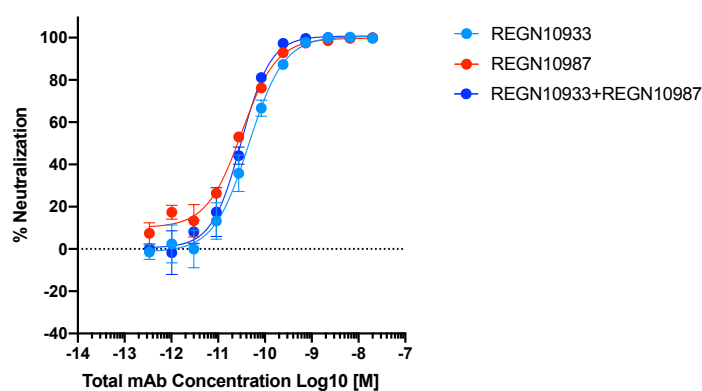

B

Fold decrease in IC50 from reference (D614G) pseudovirus

\begin{tabular}{c|c|c|c|}
\cline { 2 - 4 } Variant & REGN10933 & REGN10987 & $\begin{array}{c}\text { REGN10933+ } \\
\text { REGN10987 }\end{array}$ \\
\hline G446V & 0.4 & 135.00 & 0.48 \\
\hline S477N & 2.85 & 2.28 & 1.92 \\
\hline S494P & 4.48 & 0.98 & 1.06 \\
\hline N501Y* & 0.9 & 0.5 & 1.1 \\
\hline K537R & 1.06 & 0.82 & 0.98 \\
\cline { 2 - 4 } & &
\end{tabular}


bioRxiv preprint doi: https://doi.org/10.1101/2021.03.10.434834; this version posted May 26, 2021. The copyright holder for this preprint (which was not certified by peer review) is the author/funder, who has granted bioRxiv a license to display the preprint in perpetuity. It is made available under aCC-BY-NC-ND 4.0 International license.

\section{Figure S4}
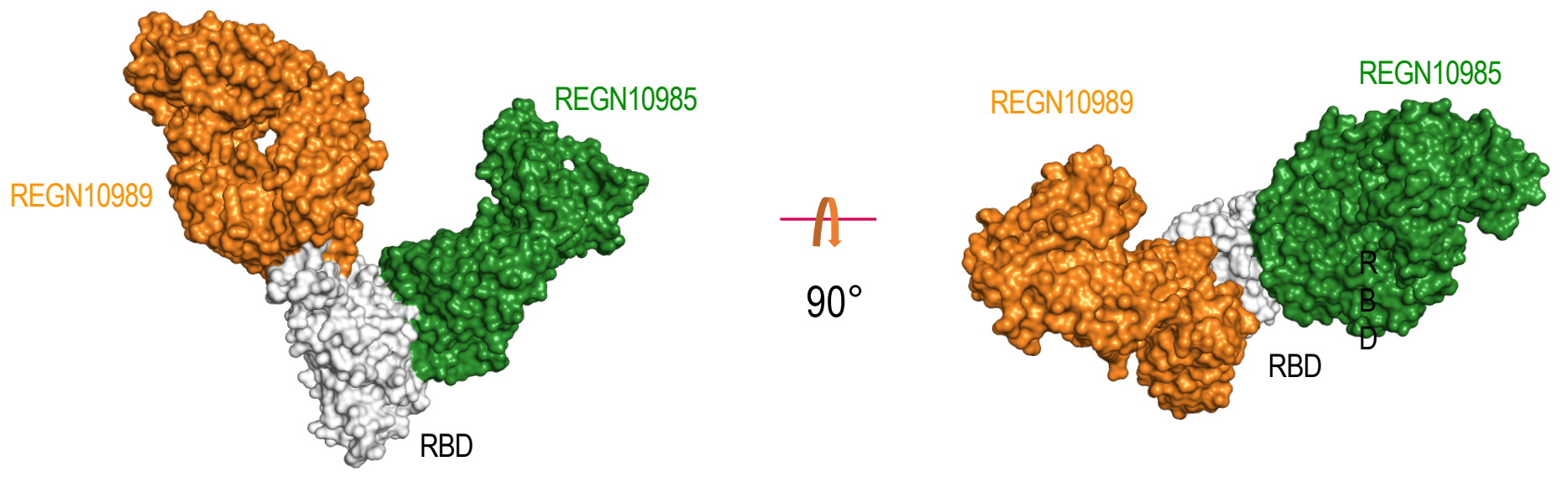
bioRxiv preprint doi: https://doi.org/10.1101/2021.03.10.434834; this version posted May 26, 2021. The copyright holder for this preprint (which was not certified by peer review) is the author/funder, who has granted bioRxiv a license to display the preprint in perpetuity. It is made available under aCC-BY-NC-ND 4.0 International license.

\section{Table S1}

\begin{tabular}{|c|c|c|}
\hline Antibody & $\begin{array}{l}\text { Mutations associated with } \\
\text { escape ( }>15 \% \text { frequency) }\end{array}$ & $\begin{array}{l}\text { Passage in which escape mutants } \\
\text { were identified }\end{array}$ \\
\hline REGN10933 & F486V (88\%) & 2 \\
\hline REGN10985 & $\begin{array}{l}\text { R408I (40\%) } \\
\text { G504D (40\%) }\end{array}$ & 1 \\
\hline REGN10987 & $\begin{array}{l}\text { K444Q (44\%) } \\
\text { V445A (40\%) }\end{array}$ & 2 \\
\hline REGN10933+REGN10987 & $\begin{array}{c}\text { K417R (100\%) } \\
\text { K444Q (100\%) } \\
\text { G476S (90\%) }\end{array}$ & 7 \\
\hline REGN10933+REGN10987+REGN10985 & None & Passaged up to P11 \\
\hline CB6 & K417N (100\%) & 1 \\
\hline LY-CoV555 & $\begin{array}{l}\text { E484K (38\%) } \\
\text { Q493R (56\%) }\end{array}$ & 1 \\
\hline CB6+LY-CoV555 & Q493R (100\%) & 2 \\
\hline COV2-2130 & K444Q (85\%) & 1 \\
\hline Cov2-2196 & $\begin{array}{l}\text { G476D (81\%) } \\
\text { N487D (18\%) }\end{array}$ & 2 \\
\hline COV2-2130+COV2-2196 & $\begin{array}{c}\text { R346G (98\%) } \\
\text { E484K (96\%) } \\
\text { F486V (100\%) }\end{array}$ & 5 \\
\hline VIR-7831 & $\begin{array}{l}\text { P337L (16\%) } \\
\text { T345P (69\%) }\end{array}$ & 2 \\
\hline
\end{tabular}


Table S2

Summary of variant frequency for each clinical group from study 2066 and 2067.

\begin{tabular}{|c|c|c|c|c|c|c|}
\hline & \multicolumn{3}{|c|}{ Study 2066} & \multicolumn{3}{|c|}{ Study 2067} \\
\hline & $\begin{array}{c}\text { Number of } \\
\text { patients }\end{array}$ & $\begin{array}{l}\text { Number of } \\
\text { samples } \\
\text { different time points }\end{array}$ & $\begin{array}{l}\text { Number of } \\
\text { variants } \\
\text { (variants pers sample) }\end{array}$ & $\begin{array}{l}\text { Number of } \\
\text { patients }\end{array}$ & $\begin{array}{l}\text { Number of } \\
\text { samples } \\
\text { different time points }\end{array}$ & $\begin{array}{c}\text { Number of } \\
\text { variants } \\
\text { (variants pers sample) }\end{array}$ \\
\hline Total & 272 & 1,336 & $244(0.18)$ & 728 & 3,546 & $514(0.14)$ \\
\hline Placebo & 91 & 472 & $90(0.19)$ & 243 & 1,215 & 216(0.18) \\
\hline Treated all & 181 & 864 & $184(0.21)$ & 485 & 2,331 & $399(0.17)$ \\
\hline $\begin{array}{c}\text { Treated low } \\
\text { dose* }^{*}\end{array}$ & 88 & 423 & $88(0.21)$ & 247 & 1,203 & $248(0.21)$ \\
\hline $\begin{array}{c}\text { Treated high } \\
\text { dose* }\end{array}$ & 93 & 441 & $109(0.25)$ & 238 & 1,128 & $212(0.19)$ \\
\hline
\end{tabular}

*low dose $=2.4 \mathrm{~g} \mathrm{IV}$

high dose $=8.0 \mathrm{~g} I \mathrm{~V}$ 
bioRxiv preprint doi: https://doi.org/10.1101/2021.03.10.434834; this version posted May 26, 2021. The copyright holder for this preprint (which was not certified by peer review) is the author/funder, who has granted bioRxiv a license to display the preprint in perpetuity. It is made

\section{Table S3} available under aCC-BY-NC-ND 4.0 International license.

\begin{tabular}{|l|l|c|c|c|}
\hline & & \multicolumn{2}{|c|}{ REGN10933 } & \multicolumn{2}{c|}{ REGN10987 } & REGN-COV2 \\
\hline \multicolumn{1}{|c|}{ Variant } & Treatment mAb & \multicolumn{2}{|c|}{ Decrease in IC50 over reference pseudovirus } \\
\hline P384L & 10987 & 1.91 & 1.29 & 1.65 \\
\hline K444T & 10987 & 1.98 & 1032.52 & 6.42 \\
\hline V445A & 10987 & 1.93 & 548.10 & 4.69 \\
\hline G446S & 10987 & N/A & N/A & N/A \\
\hline G446D & 10987 & N/A & N/A & N/A \\
\hline G446V* & N/A & 0.40 & 134.97 & 0.48 \\
\hline L455W $^{*}$ & 10933 & N/A & N/A & N/A \\
\hline L455F $^{*}$ & N/A & 79.54 & 1.06 & 1.79 \\
\hline F486S & 10933 & N/A & N/A & N/A \\
\hline F486L ${ }^{*}$ & N/A & 61.44 & 0.87 & 1.49 \\
\hline F486V* & N/A & 437.54 & 0.87 & 2.68 \\
\hline
\end{tabular}


bioRxiv preprint doi: https://doi.org/10.1101/2021.03.10.434834; this version posted May 26, 2021. The copyright holder for this preprint (which was not certified by peer review) is the author/funder, who has granted bioRxiv a license to display the preprint in perpetuity. It is made

Table S4 available under aCC-BY-NC-ND 4.0 International license.

\begin{tabular}{|c|c|c|c|c|}
\hline Study 2066 & Total & Placebo & $\begin{array}{l}\text { Treated } \\
\text { low dose }\end{array}$ & $\begin{array}{c}\text { Treated } \\
\text { high dose* }\end{array}$ \\
\hline $\begin{array}{l}\text { Number of } \\
\text { Patients }\end{array}$ & 272 & 91 & 88 & 93 \\
\hline $\begin{array}{l}\text { Number of samples } \\
\text { different time points }\end{array}$ & 1336 & 472 & 423 & 441 \\
\hline Baseline & 288 & 95 & 92 & 101 \\
\hline Day2 & 6 & 5 & 1 & 0 \\
\hline Day3 & 223 & 73 & 70 & 80 \\
\hline Day4 & 5 & 2 & 3 & 0 \\
\hline Day5 & 174 & 61 & 60 & 53 \\
\hline Day6 & 5 & 3 & 2 & 0 \\
\hline Day7 & 144 & 53 & 45 & 46 \\
\hline Day8 & 16 & 8 & 4 & 4 \\
\hline Day9 & 119 & 46 & 40 & 33 \\
\hline Day10 & 18 & 8 & 8 & 2 \\
\hline Day11 & 85 & 28 & 18 & 39 \\
\hline Day12 & 16 & 6 & 5 & 5 \\
\hline Day13 & 62 & 30 & 13 & 19 \\
\hline Day14 & 30 & 12 & 6 & 12 \\
\hline Day15 & 51 & 15 & 23 & 13 \\
\hline Day16 & 14 & 7 & 2 & 5 \\
\hline Day17 & 0 & 0 & 0 & 0 \\
\hline Day18 & 1 & 0 & 1 & 0 \\
\hline Day19 & 1 & 0 & 1 & 0 \\
\hline Day20 & 6 & 1 & 2 & 3 \\
\hline Day21 & 3 & 2 & 0 & 1 \\
\hline Day22 & 31 & 9 & 10 & 12 \\
\hline Day23 & 5 & 1 & 2 & 2 \\
\hline Day24 & 1 & 0 & 0 & 1 \\
\hline Day25 & 1 & 0 & 1 & 0 \\
\hline Day26 & 2 & 1 & 1 & 0 \\
\hline Day27 & 1 & 1 & 0 & 0 \\
\hline Day28 & 2 & 0 & 1 & 1 \\
\hline Day29 & 26 & 5 & 12 & 9 \\
\hline
\end{tabular}

*low dose $=2.4 \mathrm{~g} \mathrm{IV} \mathrm{high} \mathrm{dose}=8.0 \mathrm{~g} \mathrm{IV}$

\begin{tabular}{|c|c|c|c|c|}
\hline Study 2067 & Total & Placebo & $\begin{array}{l}\text { Treated } \\
\text { low dose* }\end{array}$ & $\begin{array}{c}\text { Treated } \\
\text { high dose* }\end{array}$ \\
\hline $\begin{array}{l}\text { Number of } \\
\text { Patients }\end{array}$ & 728 & 243 & 247 & 238 \\
\hline $\begin{array}{l}\text { Number of samples } \\
\text { different time points }\end{array}$ & 3546 & 1215 & 1203 & 1128 \\
\hline Baseline & 599 & 205 & 199 & 195 \\
\hline Day2 & 0 & 0 & 0 & 0 \\
\hline Day3 & 534 & 178 & 177 & 179 \\
\hline Day4 & 4 & 0 & 0 & 4 \\
\hline Day5 & 483 & 165 & 163 & 155 \\
\hline Day6 & 29 & 11 & 10 & 8 \\
\hline Day7 & 383 & 120 & 146 & 117 \\
\hline Day8 & 60 & 18 & 19 & 23 \\
\hline Day9 & 301 & 102 & 107 & 92 \\
\hline Day10 & 81 & 26 & 31 & 24 \\
\hline Day11 & 221 & 82 & 73 & 66 \\
\hline Day12 & 73 & 19 & 28 & 26 \\
\hline Day13 & 196 & 78 & 60 & 58 \\
\hline Day14 & 56 & 25 & 13 & 18 \\
\hline Day15 & 150 & 49 & 58 & 43 \\
\hline Day16 & 27 & 8 & 8 & 11 \\
\hline Day17 & 25 & 7 & 13 & 5 \\
\hline Day18 & 82 & 32 & 22 & 28 \\
\hline Day19 & 27 & 9 & 8 & 10 \\
\hline Day20 & 4 & 2 & 2 & 0 \\
\hline Day21 & 26 & 12 & 7 & 7 \\
\hline Day22 & 48 & 17 & 17 & 14 \\
\hline Day23 & 7 & 1 & 1 & 5 \\
\hline Day24 & 15 & 6 & 6 & 3 \\
\hline Day25 & 41 & 20 & 12 & 9 \\
\hline Day26 & 8 & 2 & 3 & 3 \\
\hline Day27 & 8 & 3 & 2 & 3 \\
\hline Day28 & 7 & 4 & 0 & 3 \\
\hline Day29 & 51 & 14 & 18 & 19 \\
\hline
\end{tabular}

${ }^{*}$ low dose $=2.4 \mathrm{~g} \mathrm{IV} \mathrm{high} \mathrm{dose}=8.0 \mathrm{~g} \mathrm{IV}$ 